\title{
The Hydro, Wind and Solar Hybrid Power Generation and Balancing Energy Supply-Demand for Seyemtribua Rural Village in Northern Ethiopia
}

\section{Getachew Tesfaye Gezahegn}

Water Supply, construction and supervision core process, Bureau of Water, Irrigation and Electricity, Wag Himra Zone, Ethiopia

Samuel Dagalo Hatiye ( $\nabla$ samueldagalo@gmail.com )

Arba Minch Water Technology Institute: Arba Minch University https://orcid.org/0000-0003-4993-2338

\section{Melkamu Teshome Ayana}

Arba Minch Water Technology Institute: Arba Minch University

\section{Abebe Temesgen Ayalew}

Arba Minch Water Technology Institute: Arba Minch University

Thomas Torora Minda

Arba Minch Water Technology Institute: Arba Minch University

Original article

Keywords: Alternative energy sources, HOMER, Energy supply-demand, Hybrid system, Rural electrification

Posted Date: July 1st, 2021

DOI: https://doi.org/10.21203/rs.3.rs-632374/v1

License: (c) (i) This work is licensed under a Creative Commons Attribution 4.0 International License.

Read Full License 


\title{
The Hydro, Wind and Solar Hybrid Power Generation and Balancing
}

\section{Energy Supply-Demand for Seyemtribua Rural Village in Northern Ethiopia}

Getachew Tesfaye Gezahegn ${ }^{1}$, Samuel Dagalo Hatiye ${ }^{2}$, Melkamu Teshome Ayana ${ }^{3}$, Abebe Temesgen Ayalew $^{3}$, Thomas Torora Minda ${ }^{4}$

${ }^{1}$ Water Supply Construction \& Supervision Core Processing Unit, Bureau of Water, Irrigation and Energy, Wag Himra Zone, Ethiopia

2 Faculty of Water Resources \& Irrigation Engineering, Arba Minch Water Technology Institute, Arba Minch University, Ethiopia.

${ }^{3}$ Faculty of Hydraulic \& Water Resources Engineering, Arba Minch Water Technology Institute, Arba Minch University, Ethiopia.

${ }^{4}$ Faculty of Meteorology \& Hydrology, Arba Minch Water Technology Institute, Arba Minch University, Ethiopia. Corresponding author: Samuel Dagalo Hatiye, E-mail: samueldagalo@gmail.com

\begin{abstract}
Background:Ethiopia has a wide range of renewable energy resources for the electrification of rural areas which are often disconnected from the national grid. However, these have not yet been utilized for supplying energy to the rural community.

Methods:The techno-economic viability of the hydro, wind, and solar hybrid power potential of Seyemtribua village in the Geba Catchment, Northern Ethiopia was evaluated using the Hybrid Optimization Model for Multiple Energy Resources (HOMER) software package. The hydrologic, meteorological, and demographic data collected from different sources were contemplated to analyze the power output and demand of the village. The simulation and optimization techniques in HOMER were employed for the possible configuration of micro-hydro, wind, and solar power hybrid systems. Besides the standalone, two and more systems were also combined to evaluate the technical capability of the
\end{abstract}


hybrid system. The hourly and daily electrical load of the community was obtained using survey data from selected households.

Results:The mean annual power output that can be harnessed from the micro-hydro, solar, and wind is 272.4 kilowat, 161.8 kilowat, and 96.8 kilowat, respectively. The combination of these energy sources is sufficient to satisfy the power demand of the village. However, the mean hourly variation of power output from the hybrid system demonstrated shortage during peak load times which can be assisted by a generator output. The economic analysis revealed that the hybrid system is feasible and cheaper than other sources of energy besides its environmental benefit.

Conclusions: The potential of energy production from hybrid systems (solar, wind and microhydro power systems) and its economic feasibility for remotely located villages in Ethiopian condition is promising. We suggest decision-makers, governmental and non-governmental agencies, power authorities, and investors consider such hybrid systems for rural electrification in Ethiopia.

Keywords: Alternative energy sources; HOMER; Energy supply-demand; Hybrid system; Rural electrification

\section{Introduction}

The UN's Sustainable Development Goal 7 (SDG7) targets to ensure access to affordable, reliable, sustainable, and modern energy for all [1]. Globally, in the year 2016, 940 million (i.e., 13\%) and 3 billion (i.e., 40\%) of the world population did not have access to electricity and clean fuels for cooking, respectively. In Sub-Saharan Africa, nearly 591 million people are without access to electricity and 86\% of the population is without clean energy for households in 2016 [2]. Degefu et al. [3] also showed that $70 \%$ of the total population does not have access to electricity, particularly in the rural remote regions. In 2019, the per capita consumption of electricity in Ethiopia was $130 \mathrm{kWh}$ [2]. 
One of the major global challenges facing the world today is the provision of reliable and costeffective energy services. Providing sufficient energy without any impediment is becoming extremely difficult. One of the major reasons that have been attributed to the low level of electricity coverage in many parts of the world is sparse rural settlements that are geographically far away from the central grid system. Many rural regions in the world are left without extensions from the central grid systems [4-6]. In most developing nations, it became financially costly and practically unfeasible to connect sparse settlements to the national grid system despite energy demands are dramatically increasing in rural villages. Moreover, energy demand for the gridded system is extremely growing from time to time [7]. This has initiated the development of large storage schemes for hydropower generation or searching for unsustainable energy sources such as coal and petroleum which are not only polluting the atmosphere and environment but also emit $\mathrm{CO}_{2}$ that can significantly contribute to climate change [8].

To surmount the drastic energy supply and demand imbalances, renewable energy resources such as micro/mini/small hydropower, solar, and wind are important especially for the off-grid rural and periurban areas. Often, standalone (e.g., hydro or solar power) energy sources are not efficient due to several reasons. Firstly, renewable energy resources are dependent on natural systems, especially climatic conditions, which are variable and uncertain. On the other hand, the operation of a single system is not reliable due to the high initial investment. When two or more renewable energy sources are combined, it can improve provision efficiency and balance the energy supply and demand. Combining energy from hydropower, wind, and solar is termed a hybrid system[9, 10]. Hybrid renewable energy systems (HRES) are becoming common since standalone power systems in remote regions are less efficient $[11,12]$.

The micro, mini or small hydropower in run-off river schemes, are schemes where a turbine generates electricity depending on the amount of water available in a river system. When the river dries up and the flow falls below some predetermined flow for the turbine, the generation of power ceases [13]. However, these systems have successfully replaced diesel generators and are better implemented in a hybrid system which consists of solar and wind power sources [14]. There are several attempts and 
success stories of these systems in Ethiopia including the Yaye, Gobecho I, Gobecho II, Ererte, Leku, Kersa, and other hydropower projects. The micro hydropower can generate power in the ranges of 11 to $500 \mathrm{KW}$; the mini between 501-1,000KW and the small hydro schemes can generate power in the range of $1,001-10,000 \mathrm{~kW}$ capacities [15].

Photovoltaic solar energy (PV) is the direct conversion of sunlight into electricity. The basic building block of the PV system is the solar module, which consists of several solar cells. Solar cells and modules come in many different forms that vary greatly in performance and degree of maturity [16]. The annual average daily radiation on a plain surface in Ethiopia is estimated to be $3.74 \mathrm{kWh} / \mathrm{m}^{2}$. The minimum annual average radiation for Ethiopia is estimated to be $1.5 \mathrm{kWh} / \mathrm{m}^{2}$ in July to a maximum of $4.9 \mathrm{kWh} / \mathrm{m}^{2}$ in February and March [17]. Thus, the use of solar power is highly feasible and becoming common in many rural villages in Ethiopia. Besides, limitation of access to the national grid and frequent power cuts are also promoting the use of solar power.

The production of power from the wind by employing modern turbines is becoming a convenient industry for power generation [18]. The wind is generated due to the pressure gradient which is resulting from uneven heating of the earth's surface by the sun. Thus, wind energy is called an indirect form of solar energy. Generation of power from wind is becoming one of the options in Ethiopian power supply schemes. Ethiopia is ranked $5^{\text {th }}$ order in Africa with $324 \mathrm{MW}$ installed wind power capacity and a national potential of $10 \mathrm{GW}$. For example, there are large wind farms in Ethiopia so far installed and operative in places such as Ashegoda (120MW installed capacity), Adama I \& II (51MW \& 153MW installed capacity) [19]. There are also several other plans for wind power development in the nation. However, there is very limited attention on the use and rehabilitation of small wind power for small off-grid villages $[20,21]$.

In Ethiopia, there is abundant renewable energy resource with the potential to generate over $60 \mathrm{GW}$ of electric power from water, wind, PV, and geothermal sources [22,23,24]. Of these renewable sources, hydropower is the most significant electric source in the country which is estimated at 
45,000MW. This potential makes Ethiopia to be the second-highest in east Africa next to the Democratic Republic of Congo. Approximately, $77.8 \%$ of this hydropower is estimated to be economically feasible with an equivalent electricity generation of $162 \mathrm{TWh}$ [3]. This is probably the reason why the nation is majorly dependent on hydropower for its power generation. In 2012, out of the 2,167MW total power generation capacity, hydropower has contributed $90.0 \%$ of the overall capacity. Diesel, wind, and geothermal sources share $6.0 \%, 3.7 \%$, and $0.3 \%$, respectively [25]. However, only about $23 \%$ of the total population of the country has been supplied by the national grid system. In the Ethiopian context, not only is the coverage but also the rate of access to electricity is quite low. The rural areas are almost disconnected from the national grid while the urban areas are connected to the grid with nearly $87 \%$ of the total power supply grid [26]. Even the urban centers where the national electricity grid exists are suffering from power shortages, frequent power cuts, and very low capacity to run appliances. This is attributed to several factors such as increased demand for hydropower, reduction of reservoir capacities, and frequent drought seasons in the nation.

Ethiopia has long been affected by recurrent drought. This has been continued even to the current century, which has also contributed to the shortage of power supply [27,28]. Moreover, there is limited experience in the use of renewable energy sources and reliance on technologies. For instance, micro/mini/small hydropower, solar photovoltaic, and wind power systems were not extensively utilized in the nation. Small hydropower, solar photovoltaic, and wind power system can easily be provided and supplied to isolated environments unlike the power supply from the national grid system. However, a single source of power system may not satisfy the demand in such isolated regions. Furthermore, dependence on a single technology increases the size of the system which can be associated with a high initial investment cost. Considering the alternating nature of renewable energy sources, the hybrid offgrid system is more preferable to enhance the reliability of the power supply than an isolated single system $[29,30]$. 
However, very little attention was given to hybrid systems and there was hardly any work attempted to estimate a reliable supply of electricity from the hybrid systems. Therefore, this study aims to (i) assess the potential power production from wind, micro-hydro, and solar hybrid system in the Geba catchment for rural electrification; (ii) estimate the power demand of typical rural village (Seyemtribua) and compare the different temporal power generation scenarios of the hybrid system and (iii) the economic feasibility of the hybrid systems considering different configurations. Governmental and nongovernmental organizations, power suppliers and authorities, researchers, water resources managers, power supply investors, practitioners, and the local community may find this study useful.

\section{Methods and materials}

\subsection{Study area}

The Geba catchment, which is the Sub-basin of Tekeze River, is located in the upper part of the Tekeze basin, Ethiopia. The catchment has an area of $3,870 \mathrm{~km}^{2}$. Its geographical location is extended between $13.3^{\circ}$ to $14.14^{\circ} \mathrm{N}$ latitude and $39.07^{\circ}$ to $39.78^{\circ} \mathrm{E}$ longitude. The elevation of the catchment varies from $1,364 \mathrm{~m}$ above mean sea level (a.m.s.l) at the outlet in the southwest of the catchment to $3,064 \mathrm{~m}$ asl at the upper part of the catchment in the northern Mugulat Mountains. River Geba is the main tributary of the Tekeze River that drains into the northeastern part of the basin. Seyemtribua is one of the villages located in the Geba catchment. The village is located near the outlet of the Geba catchment, some $95 \mathrm{~km}$ from Mekelle (capital city of Tigray Regional State, Northern Ethiopia). The annual total rainfall, mean minimum and maximum temperatures of the village are $1272 \mathrm{~mm}, 6.4{ }^{\circ} \mathrm{C}$, and $21.4{ }^{\circ} \mathrm{C}$, respectively. The village has about 3,978 inhabitants dwelling in 663 households. The Seyemtribua's community livelihood is mainly dependent on agricultural activities and traditional mining. Fig. 1 shows the location of the study area and hydro-meteorological stations used in this study. 


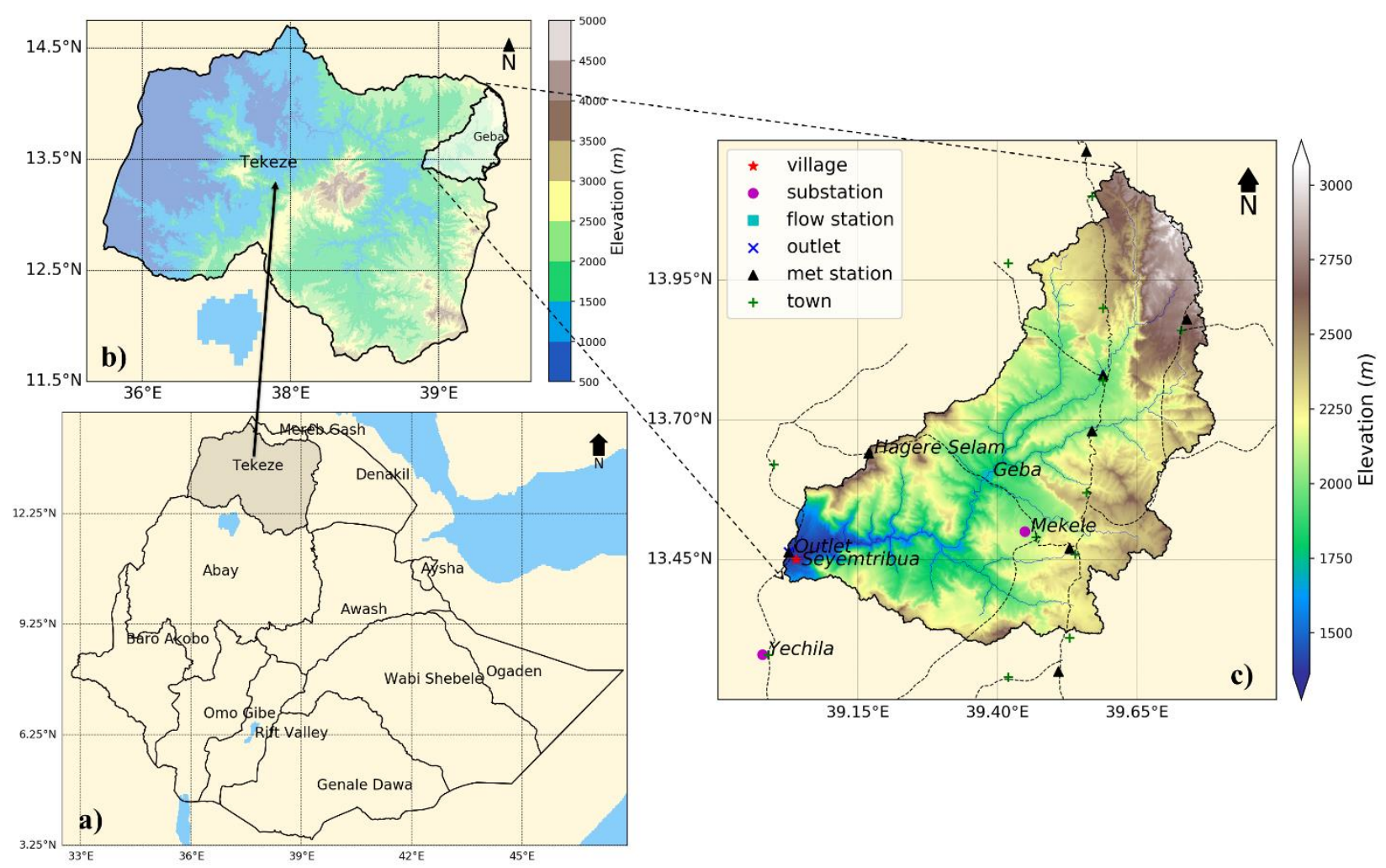

Fig. 1. Location of the study area. Map of Ethiopia with the 12 River basins of the country (a). Digital Elevation Model (DEM) of Tekeze River basin with the Geba sub-basin shown (b). DEM of the Geba sub-basin with the Seyemtribua village (c). In the plot, the Geba River (the major tributary of the Tekeze basin) with the outlet near Seyemtribua has been shown. The blue and black (broken) lines show streamlines and road networks, respectively. Mekelle and Yechila substations are located at a distant from the village

\subsection{Methods}

\subsubsection{The site selection criterion for off-grid rural electrification}

We selected the Seyemtribua village (Fig. 1) as a case study village for rural off-grid electrification based on the following criterion. First, due to natural and landscape settings, rural settlements in Ethiopia are located in dispersed areas, and hence connecting them to the national grid system is often difficult. Second, the Seyemtribua village is at distant from Mekelle and Yechila national substations. Third, the growing economy and improving living standards of the village are demanding more power (e.g., villagers have installed satellite dishes to watch TV, flour mills, shops, and entertainment centers). Fourth, urbanization across the catchment is rapidly increasing and the power- 
demanding cottage industries are growing fast. Finally, the potential availability of alternative energy sources is high in this particular study site.

\subsubsection{Data description}

We used both primary and secondary data sources in this study. The primary data sources are field surveys, wind speed measurements, and questionnaire data. The secondary data sources are meteorological and hydrological records, household and energy surveys, and solar radiation estimates from NASA. A brief description of the data used in this study is explained as follows.

The geographic locations of the village, wind power site, possible hydropower site, and climatic stations were determined using a hand-held geographic positioning system (GPS). The gross head of the river section was measured by using a tape meter. Digital Elevation Model (DEM) with a horizontal resolution of $30 \mathrm{~m} \times 30 \mathrm{~m}$ was downloaded from http://www.earthexplorer.com/. Daily streamflow data of the Geba river near the outlet was collected from the Ministry of Water, Irrigation, and Electricity (MoWIE) and used(Fig. 1). The streamflow data covers a period from 1995 to 2019. The observed meteorological data around the study site was collected from the National Meteorological Agency (NMA). Hagere Selam meteorological station, which is relatively close to the study village, was used to characterize the climatic variables of the study area (Fig. 1). As meteorological stations having wind observations are missing in the study site, wind speed data were obtained by field observation using the HTC-AVM-06 digital anemometer installed nearby the Seyemtribua village during the study period (Fig. 1). Wind observations were taken at 10m height and four times per day (06:30 AM; 12:30 PM; 06:30 PM and 12:30 AM) during the period from 17 July 2018 to 30 June 2019. The solar radiation data at the point of interest $\left(13.47^{\circ} \mathrm{N}\right.$ and $39.03^{\circ} \mathrm{E}$ and $1,380 \mathrm{~m}$ a.m.s.l) was obtained from the NASA power global meteorology database (https://docs.ropensci.org/nasapower/) [31]. We considered 24-year annual cycle radiation data.

About 365 households were interviewed using a stratified survey mechanism. This includes community classes (low, medium, and high-income), electrical appliances (such as stoves, 'injera mitad', 
etc.), social service sectors (e.g., schools, health centers, and religious institutions), and commercial load categories such as shops and small businesses to determine the power consumption of each sector. Demographic data such as population size, number of households were taken from the Tanqua Abergele district. The cost of power consumption and related information were collected from the Ethiopian Electric Power Corporation (EEPCO) district offices. Data on equipment/appliance costs related to the proposed hybrid configuration and technologies were also obtained from EEPCO.

\subsubsection{Data analysis}

The head drop along the river course was estimated by conducting a field survey. Often multicriteria decision support systems are employed to determine a hydropower site [32,33]. We selected an appropriate location at the outlet based on the following criterion. Firstly, proximity to the Seyemtribua village was taken into consideration. Secondly, an appropriate site for electro-mechanical equipment placement was considered. Thirdly, reduced cost and suitability, and road access were taken into account. Considering the three conditions, a maximum available head drop of $21 \mathrm{~m}$ was obtained. We considered this head throughout our energy calculation in this study.

Appropriate data-quality checking procedures were implemented to verify the quality of hydrometeorological data used in this study. Missing streamflow and rainfall data were filled using the normal ratio and linear regression methods [34]. Test for consistency [35] and homogeneity [36] of both rainfall and flow data were also conducted.

As the gauging station for streamflow measurement is located at Geba, we transferred the flow to the ungauged catchment near the project site (outlet) to obtain a reasonable flow at the outlet. We used the Hydrologic Modeling System (HEC-HMS) model to estimate the flow at the outlet near the village (Fig. 1). Accordingly, the Geba catchment was classified into 8 Thiessen polygons based on the avialble meteorological stations. The model was calibrated and statistically tested for its performance. For a detailed explanation of the HEC-HMS model, the reader is referred to [37]. 
For optimized use of available energy from renewable resources (hydro, wind, and solar) in the village, we used the Hybrid Optimization Model for Electrical Renewable (HOMER) modeling system [38]. A brief description of the HOMER model is given below.

\subsection{Description of the HOMER energy modeling system}

Hybrid Optimization Model for Electrical Renewable (HOMER), is an optimization model used for evaluating designs of both off-grid and grid-connected power systems for a variety of applications which contain a mix of conventional generators, cogeneration, wind turbines, solar photovoltaic, hydropower, batteries, fuel cells, biomass, and other inputs. The model simulates the operation of the micro-grid system by making energy balance calculations for each of the 8,760 hours in a year [39]. It compares the electric and thermal demand in the hour to the energy that the system can supply in that hour, and calculates the flow of energy to and from each component of the system. It also decides for each hour whether to charge or discharge the batteries and then determines whether a configuration is feasible, whether it can meet the electric demand under the conditions one specifies, and estimates the cost of installing and operating the system over the lifetime of a project. Possible decision variables in micro-grid optimization using HOMER include the size of the PV array, number of wind turbines, presence of the hydro system, size of each generator, number of batteries, size of the AC-DC converter, size of the hydrogen storage tank, and dispatch strategy [40].

\subsubsection{Hydropower potential assessment}

The power generated from hydraulic turbines is a function of the head, the flow rate, and the efficiency of the turbine. The electrical power output of the hydro-turbine was computed using Eq. [38, 41].

$$
P_{h y d}=\frac{\eta_{h y d} * \gamma_{w} * h_{n e t} * Q_{t}}{1000 w / \gamma_{w}}
$$


where $P_{h y d}$ is the power output of the hydro-turbine $[\mathrm{kw}] ; \eta_{\text {hyd }}$ is turbine efficiency $[\%] ; \gamma_{w}$ is the specific gravity of water $\left[9.81 \mathrm{~kg}^{-3}\right] ; h_{n e t}$ is the effective head $(\mathrm{m}) ; Q_{t}$ is the hydro-turbine flow rate $\left(\mathrm{m}^{3} \mathrm{~s}^{-1}\right)$.

Low flows corresponding to 90 and $95 \%$ of the probability of exceedance ( $Q_{90}$ and $\left.Q_{95}\right)$ are often used to calculate the power output of hydropower systems. Streamflow of Geba River near the outlet corresponding to $95 \%$ probability of exceedance $\left(\mathrm{Q}_{95}\right)$ was used in this study [42].

\subsubsection{Wind power potential assessment}

The wind power potential was calculated using the data from the wind station near the study area. The wind sensor was installed at $10 \mathrm{~m}$. The $10 \mathrm{~m}$ data was extrapolated at the turbine's rotor height $(\sim 50 \mathrm{~m}$ from the surface). The wind speed at the hub height of the wind turbine was computed using Eq. 2 $[43,44,45]$.

$$
U_{\text {hub }}=U_{\text {Anem }} * \frac{\ln \left(Z_{\text {hub }} / Z_{o}\right)}{\ln \left(Z_{\text {Anem }} / Z_{o}\right)}
$$

where $U_{\text {hub }}$ is the wind speed estimated at the hub height $\left(\mathrm{m}^{\cdot} \mathrm{s}^{-1}\right), U_{\text {Anem }}$ is the wind speed at anemometer height $\left(\mathrm{m}^{\prime} \mathrm{s}^{-1}\right), Z_{\text {Anem }}$ is the anemometer height $(\mathrm{m}), Z_{\text {hub }}$ is the hub height of the wind turbine $(\mathrm{m})$ and $Z_{o}$ is the surface roughness length factor $(\mathrm{m})$. We considered the surface roughness length factor equal to 0.2 since the area is covered with tall trees and shrubs [46].

The wind power potential was then determined using the wind speed at the hub height and the distance from the turbine stand to the rotor of an installed wind turbine. The power output was calculated using the wind turbine power curve for a WES30 turbine [38]. The maximum power that can be achieved through a wind turbine is nearly $60 \%$ and generator efficiency is about $80 \%$ [43]. The maximum theoretical wind energy that can be obtained from wind turbines was calculated using Eq. 1 [47,45,43].

$$
\mathrm{W}=\frac{1}{2} \mathrm{~m} v^{2}=\frac{1}{2} \rho \mathrm{V} v^{2}=0.625 \mathrm{~V} v^{2}=0.193 \mathrm{~A} v^{2}
$$


where $\rho$ is air density $\left(\sim 1.25 \mathrm{~kg} \mathrm{~m}^{-3}\right), \mathrm{V}$ is the volume $\mathrm{V}=\mathrm{A}^{*} v, \mathrm{~A}$ is rotor surface area, $v$ is wind speed.

\subsubsection{Solar power potential assessment}

The solar power was computed from the solar radiation data accessed from the NASA database. The blocked radiation energy due to the atmospheric cloudiness and other radiation barriers were considered using the clearness index $\left(\mathrm{K}_{\mathrm{t}}\right) . \mathrm{K}_{\mathrm{t}}$ is a measure of the clearness of the atmosphere, which is the fraction of solar radiation (ranges from 0 to 1 ). The extraterrestrial radiation and consecutively the

clearness index was determined based on the location of interest, i.e., latitude, longitude, and season of the year. The monthly average $\mathrm{K}_{\mathrm{t}}$ was calculated using Eq.2 [48].

$$
\mathrm{K}_{t}=\frac{H_{a v g}}{H_{0, a v g}}
$$

where, $H_{\text {avg }}$ is the monthly average radiation on the horizontal surface of the earth $\left[\mathrm{kWh} \cdot \mathrm{m}^{-2 \cdot}\right.$ day $\left.^{-1}\right], H_{o, a v g}$ is the extraterrestrial horizontal radiation, i.e., radiation on a horizontal surface at the top of the earth's atmosphere $\left[\mathrm{kWh}^{-2} \mathrm{~m}^{-\mathrm{day}^{-1}}\right]$. The procedures for determining $K_{\mathrm{t}}, H_{\text {avg, }}$ and $H_{\text {o,avg }}$ are well described elsewhere $[49,50]$.

Solar cells (photovoltaic cells) are used to convert the sun's radiation energy into electricity. To capture as much solar energy as possible, the photovoltaic panel must be oriented towards the sun depending on the latitude of a location. The HOMER model calculates the power output of the PV array using Eq.3 [38].

$$
P_{P V}=Y_{P V} f_{P V} * \frac{G_{T}}{G_{T, S T C}} *\left[1+\alpha_{P}\left(T_{C}-T_{C, S T C}\right)\right]
$$

where, $Y_{p v}$ is the rated capacity of the PV array, which is the power output under standard test condition $(\mathrm{kW}), f_{p v}$ is $\mathrm{PV}$ rating factor [\%], GT is the incident solar radiation on the PV array in the current time step $\left(\mathrm{kW} \cdot \mathrm{m}^{-2}\right), G_{T, ~ S T C}$ is the incident radiation at standard test conditions $\left(1 \mathrm{~kW} \cdot \mathrm{m}^{-2}\right), \alpha_{\mathrm{p}}$ is the temperature 
coefficient of power, $T_{C}$ is the PV cell temperature in the current time step $\left({ }^{\circ} \mathrm{C}\right)$ and $T_{C}$, sTC is the cell temperature under standard test conditions equal to $25^{\circ} \mathrm{C}$.

\subsection{Estimation of electricity load at Seyemtribua and the Workflow}

The primary and deferrable loads of the study area were classified as suggested in [51]. According to Tanqua Abergele local administration office, the village has about 663 householders with a total population size of 3,978. A simplified equation was used to determine the sample sizes given by Eq.4 [52].

$$
n=\frac{N}{1+N\left(e^{2}\right)}
$$

where $\mathrm{n}$ is the sample size, $\mathrm{N}$ is the population size, e is the acceptable sampling error with a $95 \%$ confidence level equal to 0.05 .

To estimate the electricity demand of an individual household, sampled households were interviewed and the data were converted into equivalent energy units. The total power demand of the community was calculated based on the socio-economic data.

The overall workflow of this study is shown in Fig. 2 


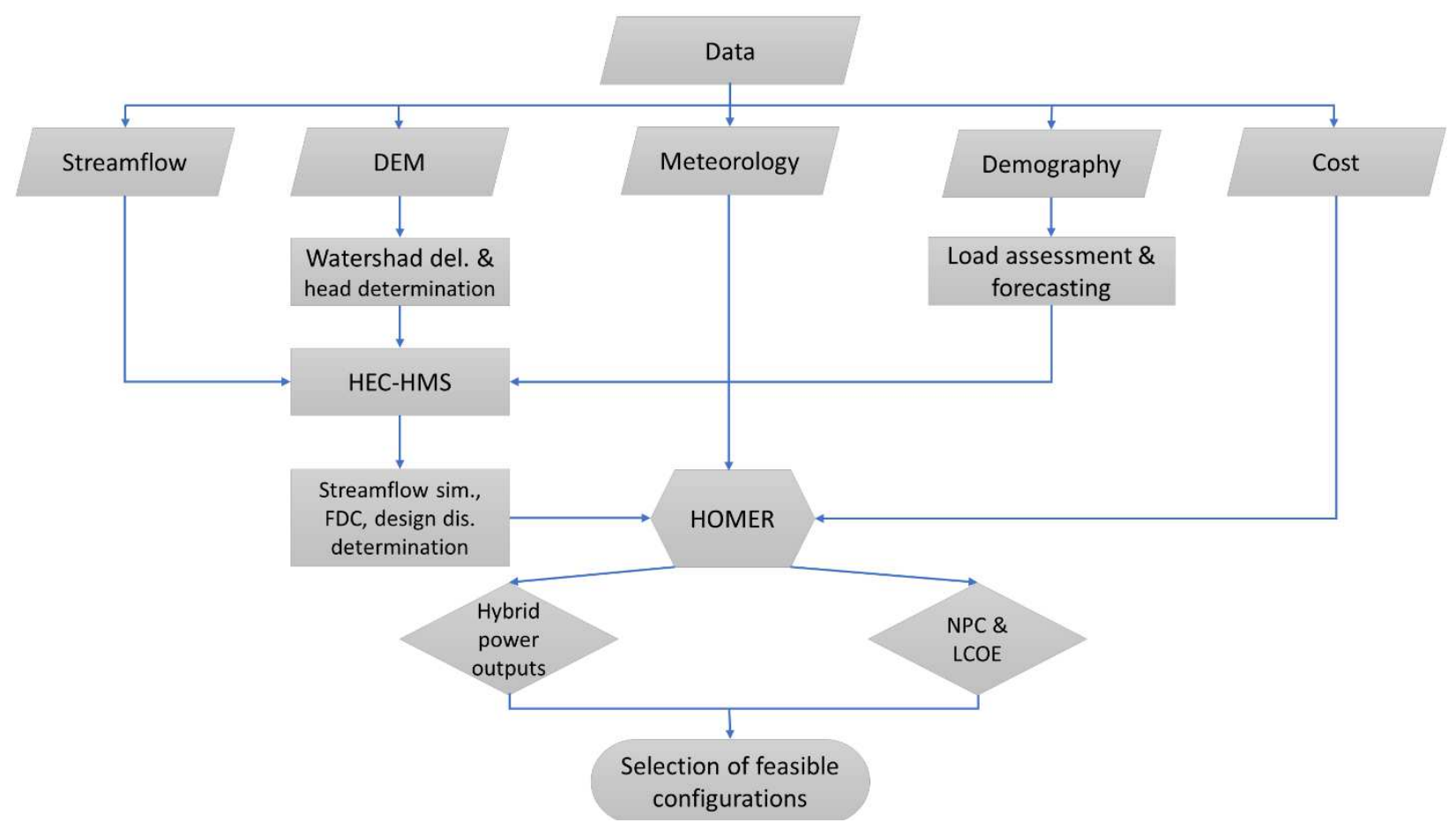

Fig. 2. Outline of procedures followed in this study

\section{Results and Discussions}

\subsection{Annual cycles of meteorological and hydrological data}

The Seyemtribua sub-catchment receives annual total rainfall of about $1273 \mathrm{~mm}$ (a daily data obtained from Hagere Selam station from 1992 to 2015). The region receives 36\%, 40\%, and 24\% of its annual total rainfall during belg, kirmet, and bega seasons ${ }^{1}$, respectively. Fig. 3 shows the annual cycle of HEC-HMS simulated streamflow at the Geba catchment outlet (a), observed 10m, and extrapolated wind at 50m (b) and radiation obtained from NASA (c). The figure shows that streamflow at the outlet (Fig. 3(a)) attains its maximum $\left(\sim 3.0\right.$ to $\left.5.5 \mathrm{~m}^{-3} \cdot \mathrm{s}^{-1}\right)$ during the kirmet season. In this wet period, wind flows and solar radiation were at the lowest values. Significant variations in streamflows, wind speed, and radiations can influence the generation of electric power from renewable energy sources.

\footnotetext{
${ }^{1}$ According to the Ethiopian Meteorological Agency (NMA), the Ethiopian climate is classified into three: belg (Feb - May), kirmet (Jun - Sep) and belg (Jan and Oct to Dec) [53].
} 

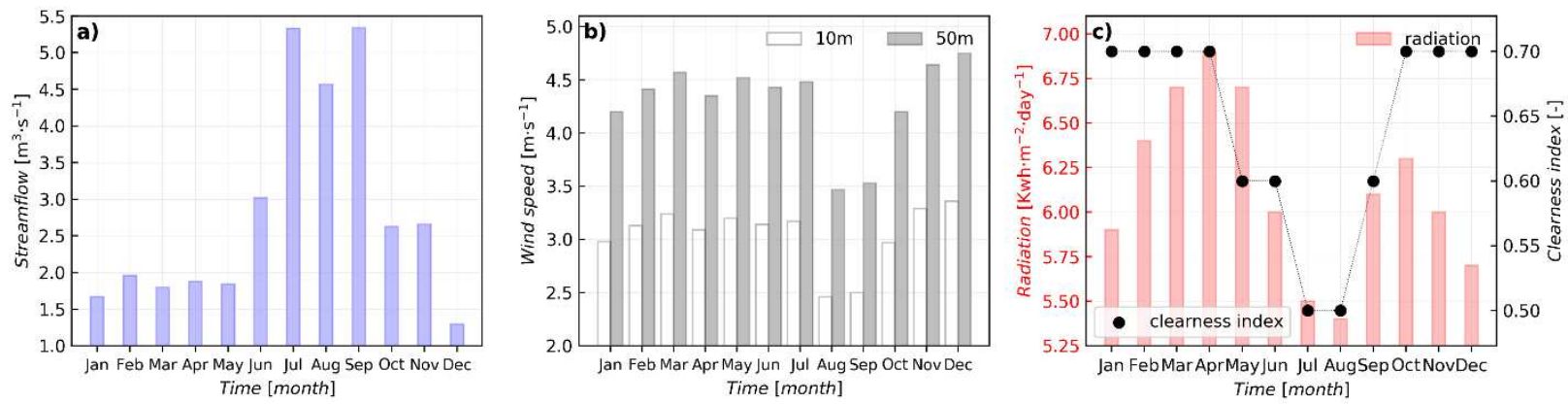

Fig. 3. Annual cycle simulated streamflow $\left(\mathrm{m}^{-3} \mathrm{~s}^{-1}\right)$ calculated by the HEC-HMS (a), measured $\left(10 \mathrm{~m}, \mathrm{~m} \cdot \mathrm{s}^{-1}\right)$ and extrapolated (50m, $\left.\mathrm{m}^{-1} \mathrm{~s}^{-1}\right)(\mathrm{b})$ and radiation $\left(\mathrm{kwh}^{-2} \cdot \mathrm{day}^{-1}\right)$ obtained from NASA database (c)

\subsection{The electricity demand of the Seyemetribua village}

In this study, we have carried out a detailed survey of loads for domestic, community, deferrable, and commercial load categories. Table 1 shows the daily appliance's load of the village for each load category. The total power demand of the community was obtained by multiplying the average power consumption of each household with the total population.

Table 1. Daily appliances load and estimated power consumption of the village. Key: Qty =Quantity; Ppn = Population; $h r=$ Hour.

\begin{tabular}{|c|c|c|c|c|c|c|c|c|c|c|}
\hline $\begin{array}{c}\text { Load } \\
\text { Category }\end{array}$ & Type & Qty & ${ }^{*}$ Ppn & Appliances & Watt & Qt & $\begin{array}{c}\text { Load in } \\
1 \mathrm{hr}\end{array}$ & Hrs & Consumption hours & $\begin{array}{c}\text { Daily } \\
\text { watt.hr }\end{array}$ \\
\hline \multirow{14}{*}{$\begin{array}{l}\text { Domestic/ } \\
\text { Residential }\end{array}$} & \multirow{2}{*}{$\begin{array}{c}\text { Low } \\
\text { income } \\
\text { household }\end{array}$} & \multirow[b]{2}{*}{494} & \multirow[b]{2}{*}{2964} & Light point & 18 & 2 & 17784 & 7 & $18,19,20,21,22,23,24$ & 124488 \\
\hline & & & & $\begin{array}{l}\text { Mobile } \\
\text { charging }\end{array}$ & 5 & 1 & 1960 & 6 & $7,8,9,18,19,20$ & 11760 \\
\hline & \multirow{5}{*}{$\begin{array}{c}\text { Middle } \\
\text { income } \\
\text { household }\end{array}$} & \multirow{5}{*}{392} & \multirow{5}{*}{2352} & Light point & 18 & 3 & 21168 & 7 & $18,19,20,21,22,23,24$ & 148176 \\
\hline & & & & Tape recorder & 100 & 1 & 39200 & 10 & $\begin{array}{l}7,8,9,10,11,18,19,20, \\
21,22\end{array}$ & 392000 \\
\hline & & & & $\begin{array}{l}\text { Mobile } \\
\text { charging }\end{array}$ & 5 & 1 & 1960 & 6 & $7,8,9,18,19,2$ & 11760 \\
\hline & & & & Stove & 1000 & 1 & 392000 & 3 & $7,12,17$ & 1176000 \\
\hline & & & & Injera Mitad & 2500 & 1 & 980000 & 1 & 13 & 980000 \\
\hline & \multirow{7}{*}{$\begin{array}{c}\text { High } \\
\text { income } \\
\text { household }\end{array}$} & \multirow{7}{*}{344} & \multirow{7}{*}{2064} & Light point & 18 & 7 & 43344 & 7 & $18,19,20,21,22,23,24$ & 303408 \\
\hline & & & & Tape recorder & 100 & 1 & 34400 & 10 & $\begin{array}{l}7,8,9,10,11,18,19,20, \\
21,22\end{array}$ & 344000 \\
\hline & & & & $\begin{array}{l}\text { Mobile } \\
\text { charging }\end{array}$ & 5 & 1 & 1720 & 6 & $7,8,9,18,19,20$ & 10320 \\
\hline & & & & Television & 200 & 1 & 68800 & 10 & $\begin{array}{l}7,8,9,13,14,18,19,20, \\
21,22\end{array}$ & 688000 \\
\hline & & & & Stove & 1000 & 1 & 344000 & 4 & $8,13,16$ & 1376000 \\
\hline & & & & Injera Mitad & 2500 & 1 & 860000 & 1 & 24 & 860000 \\
\hline & & & & Refrigerator & 120 & 1 & 41280 & 7 & $7,8,11,12,16,17,18$ & 288960 \\
\hline Community & School & 2 & 1500 & $\begin{array}{ll}\text { Class } & \text { room } \\
\text { light } & \\
\end{array}$ & 18 & 16 & 576 & 5 & $18,19,20,21,22$ & 2880 \\
\hline
\end{tabular}




\begin{tabular}{|c|c|c|c|c|c|c|c|c|c|c|}
\hline $\begin{array}{c}\text { Load } \\
\text { Category }\end{array}$ & Type & Qty & ${ }^{*}$ Ppn & Appliances & Watt & Qt & $\begin{array}{c}\text { Load in } \\
1 \mathrm{hr}\end{array}$ & Hrs & Consumption hours & $\begin{array}{c}\text { Daily } \\
\text { watt.hr }\end{array}$ \\
\hline & & & & Library & 15 & 2 & 60 & 5 & $18,19,20,21,22$ & 300 \\
\hline & & & & $\begin{array}{l}\text { Administrator } \\
\text { office }\end{array}$ & 15 & 1 & 30 & 5 & $18,19,20,21,22$ & 150 \\
\hline & & & & Staff offices & 15 & 2 & 60 & 5 & $18,19,20,21,22$ & 300 \\
\hline & & & & $\begin{array}{l}\text { Teacher's' } \\
\text { house }\end{array}$ & 11 & 10 & 220 & 7 & $18,19,20,21,22,23,24$ & 1540 \\
\hline & & & & External light & 15 & 4 & 120 & 12 & $18,19,20,21,22,23,24$ & 1440 \\
\hline & & & & $\begin{array}{ll}\text { Toilet } & \text { room } \\
\text { light } & \end{array}$ & 11 & 2 & 44 & 7 & $18,19,20,21,22,23,24$ & 308 \\
\hline & & & & Computer & 250 & 3 & 1500 & 7 & $9,10,11,14,15,16,17$ & 10500 \\
\hline & & & & Printer & 250 & 1 & 500 & 7 & $9,10,11,14,15,16,17$ & 3500 \\
\hline & \multirow{9}{*}{$\begin{array}{l}\text { Health } \\
\text { center }\end{array}$} & \multirow{9}{*}{2} & \multirow{9}{*}{100} & Room lighting & 18 & 6 & 216 & 12 & $\begin{array}{l}1,2,3,4,5,18,19,20,21, \\
22,23,24\end{array}$ & 2592 \\
\hline & & & & External light & 15 & 2 & 60 & 12 & $\begin{array}{l}1,2,3,4,5,18,19,20,21, \\
22,23,24\end{array}$ & 720 \\
\hline & & & & Extension room & 18 & 2 & 72 & 5 & $18,19,20,21,22$ & 360 \\
\hline & & & & Television & 200 & 1 & 400 & 9 & $\begin{array}{l}8,9,10,11,18,19,20,21 \\
, 22\end{array}$ & 3600 \\
\hline & & & & $\begin{array}{l}\text { Lab. } \\
\text { Microscope }\end{array}$ & 20 & 1 & 40 & 8 & $8,9,10,11,14,15,16,17$ & 320 \\
\hline & & & & Ceiling Fun & 100 & 4 & 800 & 9 & $\begin{array}{l}11,12,13,14,15,16,17, \\
18,19\end{array}$ & 7200 \\
\hline & & & & Vaccine freezer & 250 & 1 & 500 & 10 & $\begin{array}{l}8,9,10,11,12,14,15,16 \\
, 17,18\end{array}$ & 5000 \\
\hline & & & & Computer & 250 & 2 & 1000 & 11 & $\begin{array}{l}9,10,11,14,15,16,17,1 \\
8,19,20,21\end{array}$ & 11000 \\
\hline & & & & Printer & 250 & 1 & 500 & 7 & $\begin{array}{l}9,10,11,14,15,16,17,1 \\
8,19,20\end{array}$ & 3500 \\
\hline & \multirow{2}{*}{ Church } & \multirow{2}{*}{3} & & Light point & 18 & 5 & 270 & 13 & $\begin{array}{l}1,2,3,4,5,6,18,19,20,2 \\
1,22,23,24\end{array}$ & 3510 \\
\hline & & & & Megaphone & 15 & 1 & 45 & 11 & $\begin{array}{l}1,2,3,4,5,6,7,8,17,18, \\
19\end{array}$ & 495 \\
\hline \multirow{2}{*}{ Commercial } & \multirow{2}{*}{$\begin{array}{l}\text { Flour } \\
\text { mille }\end{array}$} & \multirow{2}{*}{2} & & Light point & 6 & 18 & 324 & 7 & $16,17,18,19,20,21,22$ & 2268 \\
\hline & & & & Flour mille & 12500 & 2 & 50000 & 7 & $11,12,13,16,17,18,19$ & 350000 \\
\hline \multirow[t]{2}{*}{ Deferrable } & \multirow{2}{*}{$\begin{array}{l}\text { Water } \\
\text { supply }\end{array}$} & \multirow[t]{2}{*}{1} & \multirow[t]{2}{*}{8980} & Light point & 18 & 3 & 54 & 14 & $\begin{array}{l}1,2,3,4,5,6,17,18,19,2 \\
0,21,22,23,24\end{array}$ & 756 \\
\hline & & & & Water pump & 3000 & 4 & 12000 & 6 & $1,2,3,4,5,6$ & 72000 \\
\hline
\end{tabular}

The detail of hourly electric power consumption for primary and deferrable loads of the village is presented in Table 2. The table shows that power inevitability for domestic and primary loads is maximal whereas, community and deferrable loads are minimal. Except for deferrable and commercial loads, the peak power consumption times run from 07:00 to 15:00 and between 16:00 and 18:00 hours (Table 2). These periods are when hefty energy demands for cooking and other purposes are mandatory compared to the other demands. 
Table 2. Hourly average power load of the Seyemtribua village, Northern Ethiopia

\begin{tabular}{|c|c|c|c|c|c|c|c|}
\hline $\begin{array}{l}\text { Time of power } \\
\text { consumption }(\mathrm{hr})\end{array}$ & $\begin{array}{l}\text { Domestic } \\
(\mathrm{kWh})\end{array}$ & $\begin{array}{l}\text { Community } \\
(\mathbf{k W h})\end{array}$ & $\begin{array}{l}\text { Commercial } \\
(\mathbf{k W h})\end{array}$ & $\begin{array}{l}\text { Primary } \\
\text { load }(k W h)\end{array}$ & $\begin{array}{l}\text { Deferrable } \\
(\mathbf{k W h})\end{array}$ & $\begin{array}{l}\text { Total } \\
(\mathbf{k W h})\end{array}$ & load \\
\hline 01:00-02:00 & 0 & 0.71 & 0 & 0.71 & 12.05 & 12.77 & \\
\hline 02:00-03:00 & 0 & 0.71 & 0 & 0.71 & 12.05 & 12.77 & \\
\hline 03:00-04:00 & 0 & 0.71 & 0 & 0.71 & 12.05 & 12.77 & \\
\hline 04:00-05:00 & 0 & 0.71 & 0 & 0.71 & 12.05 & 12.77 & \\
\hline 05:00:06:00 & 0 & 0.71 & 0 & 0.71 & 12.05 & 12.77 & \\
\hline 06:00-07:00 & 0 & 0.32 & 0 & 0.32 & 12.05 & 12.37 & \\
\hline 07:00-08:00 & 581.32 & 0.05 & 0 & 581.37 & 0 & 581.37 & \\
\hline 08:00-09:00 & 533.32 & 0.99 & 0 & 534.31 & 0 & 534.31 & \\
\hline 09:00-10:00 & 148.04 & 4.44 & 0 & 152.48 & 0 & 152.48 & \\
\hline 10:00-11:00 & 73.6 & 4.44 & 0 & 78.04 & 0 & 78.04 & \\
\hline 11:00-12:00 & 114.88 & 5.24 & 50 & 170.12 & 0 & 170.12 & \\
\hline $12: 00-13: 00$ & 777.28 & 1.3 & 50 & 828.58 & 0 & 828.58 & \\
\hline 13:00:14:00 & 1048.8 & 0.8 & 50 & 1099.6 & 0 & 1099.6 & \\
\hline $14: 00-15: 00$ & 928.8 & 4.84 & 0 & 933.64 & 0 & 933.64 & \\
\hline $15: 00-16: 00$ & 0 & 4.84 & 0 & 4.84 & 0 & 4.84 & \\
\hline $16: 00-17: 00$ & 385.28 & 4.84 & 50.32 & 440.44 & 0 & 440.44 & \\
\hline 17:00-18:00 & 777.28 & 4.89 & 50.32 & 832.49 & 0.05 & 832.54 & \\
\hline 18:00-19:00 & 271.62 & 4.47 & 50.32 & 326.41 & 0.05 & 326.47 & \\
\hline 19:00:20:00 & 230.34 & 3.97 & 50.32 & 284.63 & 0.05 & 284.69 & \\
\hline 20:00-21:00 & 230.34 & 3.13 & 0.32 & 233.79 & 0.05 & 233.84 & \\
\hline 21:00-22:00 & 224.7 & 3.13 & 0.32 & 228.15 & 0.05 & 228.2 & \\
\hline $22: 00-23: 00$ & 224.7 & 2.13 & 0.32 & 227.15 & 0.05 & 227.2 & \\
\hline 23:00:00:00 & 82.3 & 0.93 & 0 & 83.23 & 0.05 & 83.28 & \\
\hline 00:00-1:00 & 82.3 & 0.93 & 0 & 83.23 & 0.05 & 83.28 & \\
\hline Sum & 6714.87 & 59.22 & 352.27 & 7126.36 & 72.76 & 7199.11 & \\
\hline
\end{tabular}




\subsection{Temporal variations of modeled renewable energy outputs}

\subsubsection{Hourly variations (on yearly basis) of standalone renewable energy outputs}

The annual energy generated from various renewable energy sources was calculated by the HOMER software. The model output shows that the annual energy produced by small hydro, wind turbines, and PV array hybrid system were estimated to be $2.38 \mathrm{GWh}, 0.85 \mathrm{GWh}$, and $1.42 \mathrm{GWh}$, respectively. In order to compensate for the shortfall of high-energy demand, diesel generators were also suggested for nearly 1,547 hours on average in a year to enhance the power production of $0.12 \mathrm{GWh}^{\text {year }}{ }^{-}$

1. The capacity of hydropower output is $272 \mathrm{~kW}$ and its mean output is only $214 \mathrm{~kW}$ resulting in a capacity factor (CF) of $78.7 \%$. The average annual power that can be harnessed from the wind turbines is $96.8 \mathrm{~kW}$ with a maximum of $2,000 \mathrm{~kW}$ corresponding to CF of $4.8 \%$. The rated capacity of the PV array is $766 \mathrm{~kW}$, with the mean output of $162 \mathrm{~kW}$ and the capacity factor equal to about $21.1 \%$. In comparison to hydro and PV array, the solar source has very low CF signifying low output despite its high initial investment cost. Fig. 4 shows hourly model power outputs that can be harnessed from each component of the hybrid system throughout the year. 

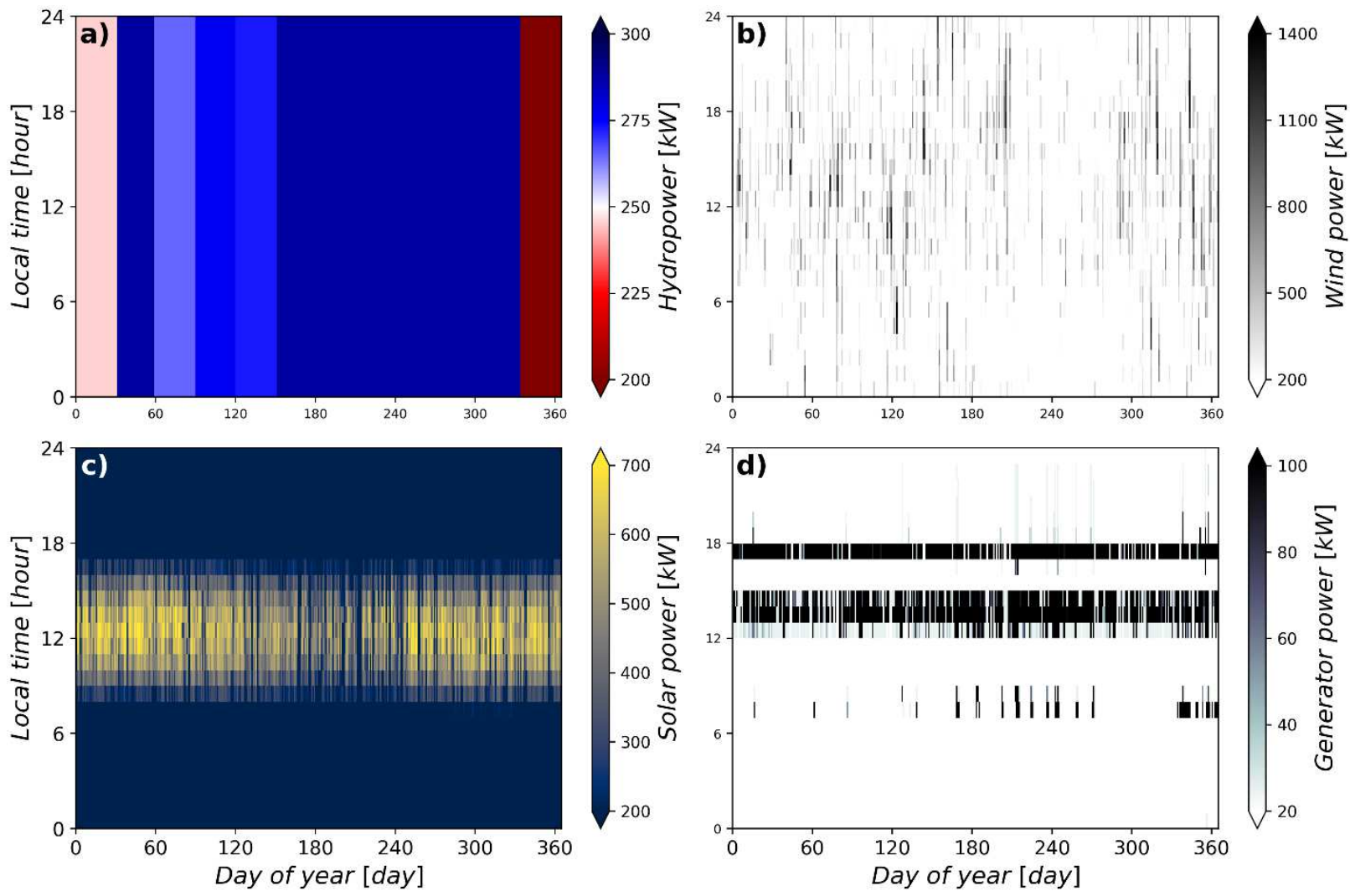

Fig. 4. Hourly variations (y-axes) variations of power output throughout the year: (a) small hydropower, (b) wind power, (c) solar power, and (d) diesel power. NB: all the units are $k W$

The hourly small hydropower production over the year indicates that the possibility of power production above average for most of the period (Fig. 4a). However, hydropower alone could not suffice the power requirement. On the other hand, wind power production falls far below the average power output across different hours of the year (Fig. 4b). During daytime when there is peak radiation from the sun (usually from 8:00 - 16:00), the production of power from the PV array shoots up (Fig. 4c). However, none of the sources alone can meet the demand of the consumers at the peak time when the community consumes maximum power for cooking and other daily uses. In this situation, power demand cannot be met and additional power may be supplied from a diesel generator. However, the diesel power supply is neither healthy nor environment-friendly and not a sustainable energy option (Fig. 4d).

In general, it can be shown that hydro, solar, and wind power sources can generate a significant amount of energy for off-grid locations. Given production of power from a hybrid system is guaranteed, 
the only limitation that may hinder power supply in rural areas might be the storage of the surplus energy that can be generated from these sources. Storage batteries are supposed to store excess energy which can be used to smooth the power fluctuation in the component sources such as PV cells and the wind sources $[54,55]$. The stored energy can be utilized later when the demand exceeds the energy generation. The bottleneck, however, is the cost and management of the battery for small rural villages like Seyemtribua. Therefore, power consumption management and scheduled use of power could be better alternatives.

\subsubsection{Annual cycle of power output}

It has been implicit that using only one mode of power source cannot meet the required power demand of the community. Rather, multiple power sources can be adapted to meet the demand. As supply from a standalone system fails to fulfill the demand, various power options can be combined and supplied. Fig. 5 depicts the mean monthly micro-hydro, wind, PV array, and diesel power output that can be harnessed in a year for the study area. The power demanded is also showed in the plot (right side yaxis). 


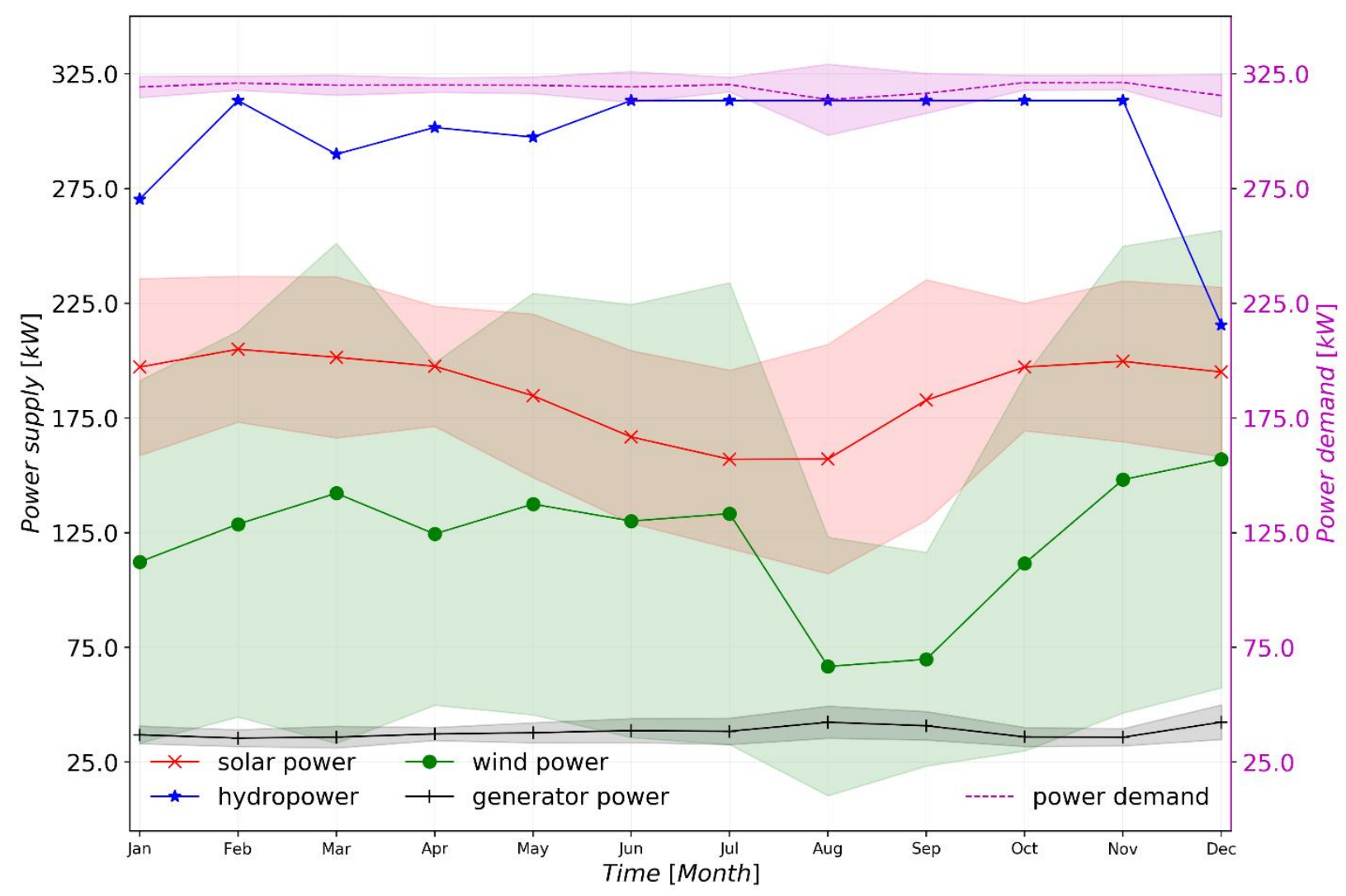

Fig. 5. Annual cycle of power supply (hydro, wind, PV array, and diesel generator) and power demand in a year (the right-side y-axis). The shaded regions show mean \pm standard deviations. Both statistical measures are applied to daily mean data

The mean monthly hydropower production is the highest of all the other power sources (Fig. 5). Since hydropower units fully depend on the water flow, a maximum of $288 \mathrm{~kW}$ power production can be achieved during the kiremt season (June to November) when the flow in the river course is high. The hydropower potential falls to $190.6 \mathrm{~kW}$ during the dry season (January and December). The mean production recorded from the wind source is around $96.8 \mathrm{~kW}$ with a maximum output of $132 \mathrm{~kW}$ in December. During August and September, the power production declines to 41.7 to $44.8 \mathrm{~kW}$. During the rainy season (in kiremt), photovoltaic power production units are in the lowest power production because of the increased cloudiness, which reduces the incoming radiation (Fig. 3c). The total energy that can be produced from the hybrid system is $4.68 \mathrm{GWh}^{-y e a r}{ }^{-1}$ of which $50.9 \%$ is produced using small hydro, $11.3 \%$ is from wind, $34.5 \%$ is from PV array and $3.3 \%$ is diesel energy. 
To adequately satisfy the power demand, which is around $2.63 \mathrm{GWh}^{-} \mathrm{year}^{-1}$, the combined power production of nearly $4.68 \mathrm{GWh}^{\text {year }}{ }^{-1}$ from hydro, wind, and solar together is sufficient to meet the power requirement of the community. The generator power supply is meant for any emergency use if and only if the combined power generation fails for some reason. Only under exceptional circumstances, diesel operated generators can be used to meet the demand hence can be defined as a standby source. The wind power supply is largely fluctuating as shown in Fig. 5, though consistency lies with solar and hydropower production. The power demand of the community on an hourly basis during a day is significantly variable (Table 2). Similarly, the power supply may also vary on daily basis. Section 3.3.3 presents the diurnal cycle of modeled power output.

\subsubsection{Diurnal cycle of power output}

Earlier sections depict the average monthly power productions of each component of the hybrid system. The average power production on monthly basis does not explicitly show significant variations from month to month (Fig. 5). This may be attributed to the fact that coarser time scales (e.g., monthly) data has a lumping effect on the extreme conditions (both low and high power production/consumption) to describe the power production/consumption. Such information may be useful for average power production and consumption conditions and may not provide useful information for power consumption and production for finer time scales. On an hourly basis, power supply and demand variations are large mainly for solar power and demanded power (Fig. 6). The figure shows the mean diurnal variation of all the alternative energy sources and the community power demand. 


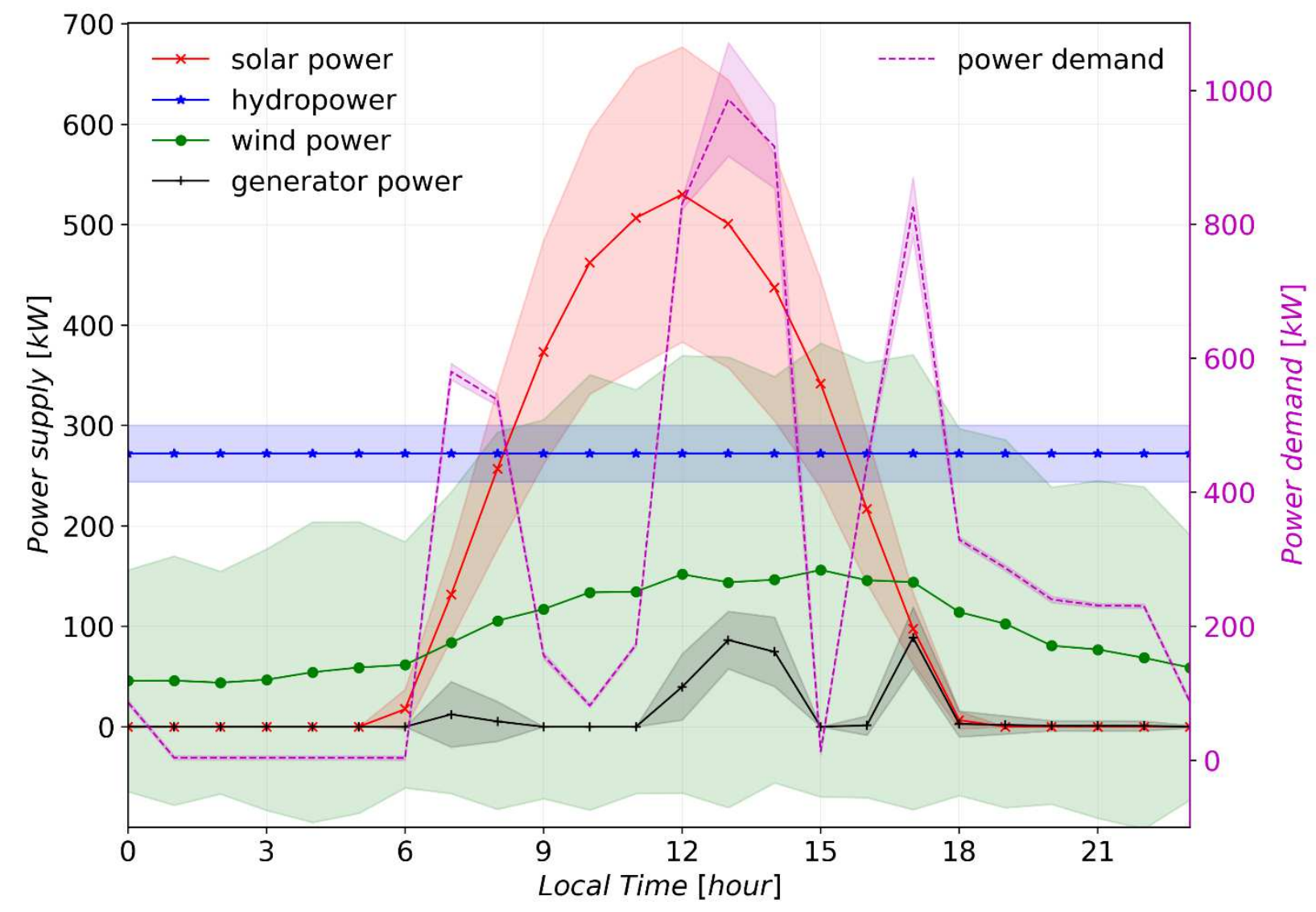

Fig. 6. Diurnal cycle of power output (hydro, wind, PV array, and diesel generator) and power demand (the right-side y-axis) variations. The shaded regions show mean \pm standard deviations calculated on hourly data

Hydropower output does not show diurnal variability and is constant throughout the day $(\sim 280$ $\mathrm{kW}$ ) (Fig. 6). The solar power shows diurnal variations and it follows the sun's angle with peak power around $\sim 500 \mathrm{~kW}$ at mid-day. The solar power supply alone cannot serve the community during power demands during peak hours (i.e., 6:00-9:00, 11:00-18:00, and 16:00-18:00) (Fig. 6, right y-axis). Wind power generation on an hourly basis is quite low in comparison to the other renewable energy sources. It is interesting to note that a power backup battery is needed to store surplus power at non-peak hours. This could help the community to compensate for the power requirement during breakfast, lunch, and dinner preparation hours. 


\subsection{Power supply and demand balance}

\subsubsection{Monthly supply and demand balance}

Our analyses show that a standalone power generation supply cannot satisfy the consumers' energy demand both on monthly and daily time scales (Fig. 5 and Fig. 6). This implies that a combined power metrics is needed to maintain the demand-supply balance (Fig. 7).

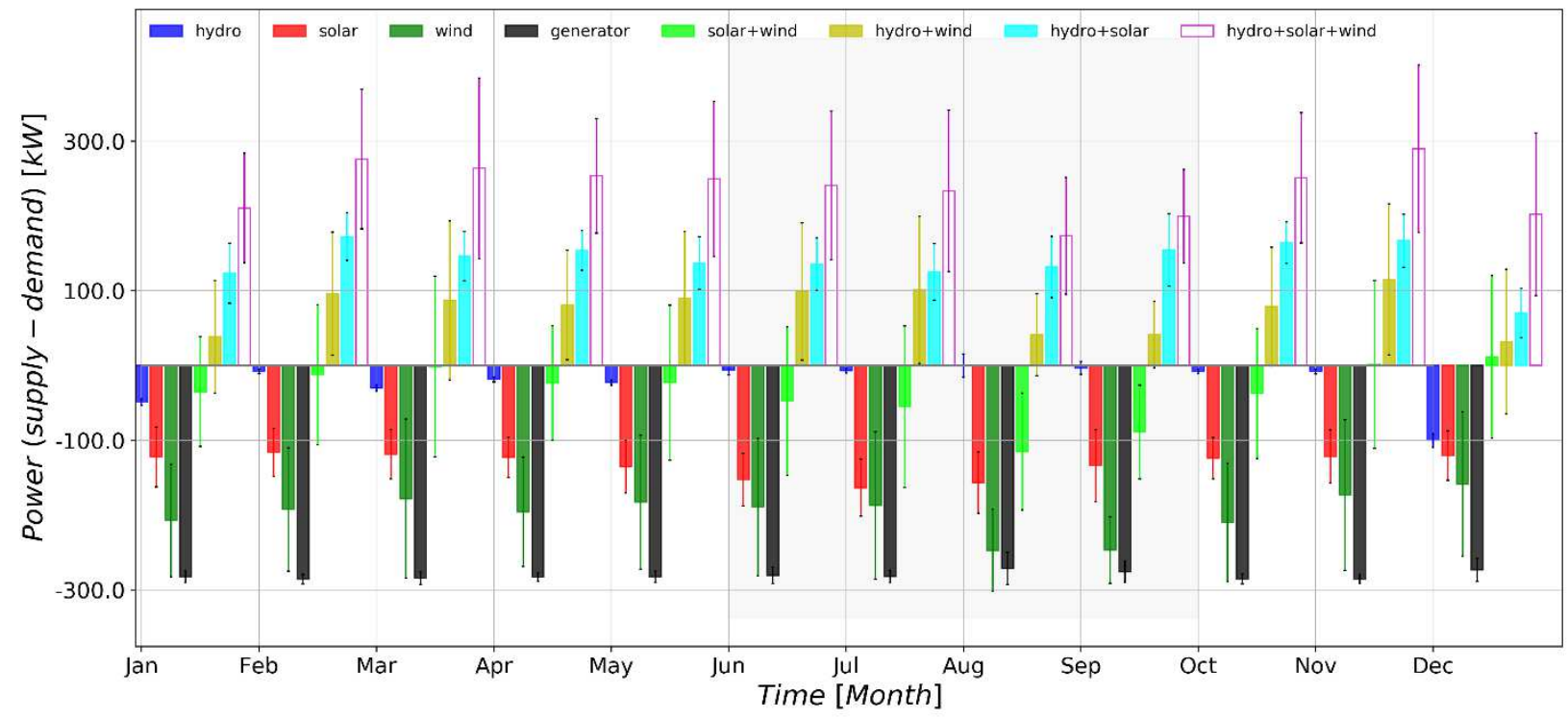

Fig. 7. Change in mean monthly power output of renewable energy sources as compared to the power demand (i.e., power supplied minus power demanded) for the Seyemtribua rural district

Although the power production from the hydropower source seems sufficient in some months of the year (e.g., August and September), it cannot satisfy the power demand of the community in most other months (Fig. 5 and Fig. 7). For northern Ethiopia, the period from June to September is a period when there is high rainfall, low solar, and less windy ( conditions prevail Fig. 3). These environmental factors result in the generation of high hydropower and low solar and wind power during the kirmet season (Fig. 5).

The wind and solar systems, on the other hand, can also do not satisfy the power demanded. Hence, none of the standalone power system can satisfy the power needed. To provide sufficient energy for the community, a hybrid system is recommended. A combination of solar \& wind is not sufficient to 
satisfy the power demand of the community. On the other hand, the combination of hydro, solar \& wind can produce surpluse power than demanded. The hybrid system with combinations of hydro \& wind or hydro \& solar is sufficient to satisfy the power demand of the community on a monthly time scale. Such

hybrid systems are commonly suggested for harnessing renewable energies [11,12]. The micro to small hydropower schemes integrated with the other alternative renewable energy sources can be potential power sources for scattered rural and semi-urban settlements in Ethiopia [56,11,57]. Some of the combinations of energy sources satisfy the community power demand on a monthly basis. It is interesting to investigate whether these combinations fulfill the power demanded on an hourly time scale.

\subsubsection{Supply and demand balance during a day}

Table 2 showed that the power demand of the community is significantly varied during a given day. The power supply and demand balance on monthly basis is shown in Fig. 7 may not show the power balance on the hourly time scale. Fig. 8 presents the power balance (i.e., supply minus demand) on a diurnal time scale for the hybrid systems as explained in Fig. 7. 


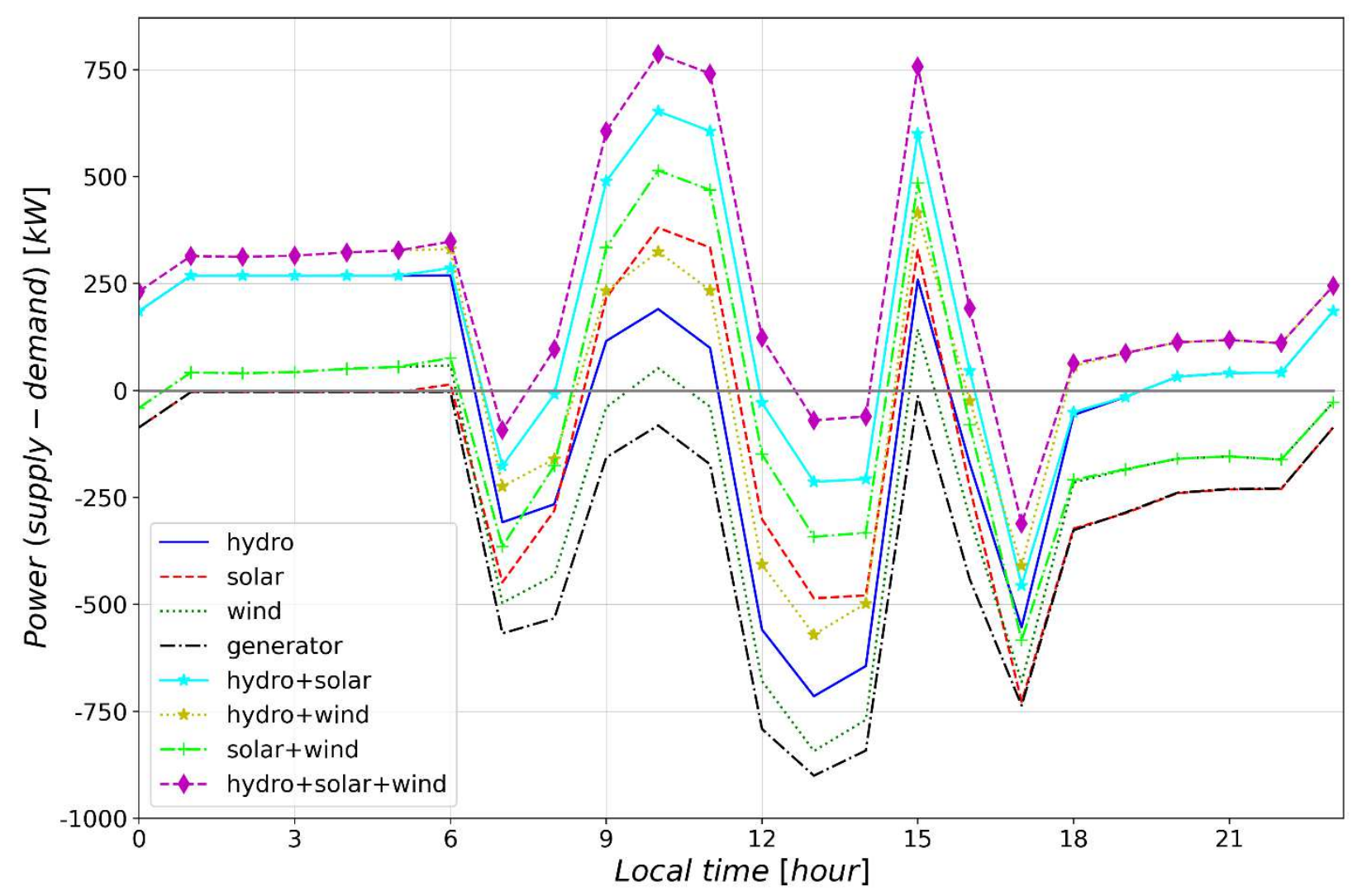

Fig. 8. Diurnal cycle of power balance (power supplied minus power demanded) for different power combination alternatives for the Seyemtribua rural area

Any combination with hydro (i.e., hydro \& solar or hydro \& wind), for example, satisfies the power demand of the community. A hybrid system of hydro, solar, and wind can provide much surplus power if we consider energy balance on a monthly time scale (Fig. 7). However, these systems cannot satisfy the power demand of the community during peak hours (breakfast, lunch, and dinner preparation hours) of the day (Fig. 8). It is also interesting to note that surplus power is prevalent during off-peak hours. To meet the required demand during peak hours, the combination of all alternative power sources has to be taken into account. One of the following options can be followed: (1) excess power production during off-peak hours can be stored and reused during the predicament periods; (2) advising the community to shift load demands to off-peak hours; (3) diesel generators can be supplied at peak hours (6:00-9:00, 11:00-14:00, and 16:00-18:00), but this option needs consideration of the environmental impact of the non-renewable energy option. From the three scenarios, planning and implementing 
alternative power consumption strategies which reduce demand in peak hours may be the most feasible of all others. The limitation is that the option needs awareness creation and change of power consumption behavior in the community.

\subsection{An economic evaluation of the standalone and the hybrid System}

\subsubsection{An economic evaluation of the standalone system}

The costs of micro-hydro power, the PV, and wind systems were considered separately for the standalone system. This is to evaluate the costs of a single system before suggesting the hybrid system. The cost of a hydropower system in Ethiopia is relatively low. Hydropower installation in Ethiopia costs about US\$1,200 per installed $\mathrm{kW}$ or about half the cost of most other plants being built in eastern Africa. Thus, unit generation costs of planned hydropower plants are calculated to be below $\$ 0.05 / \mathrm{kWh}$. The Levelized cost for transmission is estimated to be $\$ 0.007 / \mathrm{kWh}$. This figure for the distribution system is estimated to be $\$ 0.014 / \mathrm{kWh}$. Therefore, the total Levelized cost of power supply for hydropower plants is estimated at $\$ 0.067 / \mathrm{kWh}$, one of the lowest in the World [15]. However, it should be noted that expenses are dependent on the condition and cost of transportation, civil work, and technology offered in the mountainous landscapes.

Wind turbine cost varies based on the technology used and tower height. Costs of civil work and installation of wind turbines also vary based on site condition and turbine size [58]. The wind turbine selected in this study for the system was $250 \mathrm{~kW}$. The specification for the wind turbine was adopted from the literature following the recommendations in HOMER [38] package. Capital cost was considered to be $\$ 65,000$ including turbine cost and installation. The replacement cost amounting to $\$ 50,000$ was considered while the operating and maintenance costs were assumed to incur nearly $\$ 500 / y$. The number of wind turbine units to be considered was optimized by the HOMER software package. The cut-in wind speed of $2.7 \mathrm{~m} / \mathrm{s}$ and cut-out wind speed of $25 \mathrm{~m} / \mathrm{sec}$ with a life expectancy of 20 years was considered. Among the three WES types of turbine, the WES with $48 \mathrm{~m}$ hub height, 2 bladed upwind and rotor 
diameters of 30m (WES250) were selected [40]. For a new turbine, the operation and maintenance costs may easily make up 20-25\% of the Levelized cost per kWh produced over the life of the turbine [59].

PV array costs vary based on their technology. In general, a PV costs $\$ 1.60 / W$. Average residential solar system prices have been decreased to $\$ 1.16 / \mathrm{W}$ due to several factors, including changes to the composition of the solar choice installer network and updated pricing from installers [60]. The capital costs of a PV system included costs of the PV array, other costs such as labor, installation, and structure. Therefore, the cost for PV was considered about $\$ 1800 / \mathrm{kW}$. The replacement cost is almost equivalent to the capital cost. Indeed, solar energy does not require maintenance compared to the other generation sources, PV solar plants are investments that are likely to last for 20 to 25 years or more. Operating and maintenance costs are not high for a PV system and are assumed to be $\$ 10 / \mathrm{kW}$ per year. Considering all the component costs and power generations, feasible configurations were identified. HOMER software was also used to assess the economic viability of each renewable energy source considered in this study. The most feasible combinations of the standalone hybrid system are presented in Table 3. 
Table 3. Configuration of standalone hybrid feasible system components

\begin{tabular}{|c|c|c|c|c|c|c|}
\hline No & $\begin{array}{l}{ }^{\ddagger} \mathbf{P V} \\
(\mathbf{k W})\end{array}$ & $\begin{array}{c}\text { WES250 } \\
(\mathbf{k W})\end{array}$ & $\begin{array}{c}\text { Gen } 100 \\
(\mathbf{k W})\end{array}$ & $\begin{array}{c}\text { Surr6CS25P } \\
(\mathbf{k W})\end{array}$ & $\begin{array}{l}\text { Hyd } 1009 \\
(k W)\end{array}$ & $\begin{array}{c}\text { Solax10 } \\
(\mathbf{k W})\end{array}$ \\
\hline 1 & 903 & 5 & 100 & 588 & 214 & 689 \\
\hline 2 & 915 & 5 & 100 & 582 & 214 & 689 \\
\hline 3 & 974 & 4 & 100 & 571 & 214 & 686 \\
\hline 4 & 906 & 5 & 100 & 569 & 214 & 695 \\
\hline 5 & 891 & 5 & 100 & 598 & 214 & 694 \\
\hline 6 & 907 & 5 & 100 & 536 & 214 & 703 \\
\hline 7 & 911 & 5 & 100 & 611 & 214 & 688 \\
\hline 8 & 819 & 5 & 100 & 591 & 214 & 712 \\
\hline 9 & 917 & 6 & 100 & 600 & 214 & 681 \\
\hline 10 & 908 & 6 & 100 & 574 & 214 & 689 \\
\hline 11 & 858 & 5 & 100 & 593 & 214 & 705 \\
\hline 12 & 932 & 4 & 100 & 598 & 214 & 696 \\
\hline 13 & 905 & 5 & 100 & 605 & 214 & 693 \\
\hline 14 & 888 & 5 & 100 & 581 & 214 & 702 \\
\hline 15 & 895 & 6 & 100 & 589 & 214 & 691 \\
\hline 16 & 948 & 4 & 100 & 575 & 214 & 698 \\
\hline 17 & 890 & 4 & 100 & 533 & 214 & 721 \\
\hline 18 & 1,033 & 4 & 100 & 555 & 214 & 681 \\
\hline 19 & 1,041 & 4 & 100 & 496 & 214 & 692 \\
\hline $\begin{array}{l}{ }^{{ }^{F} P V} \\
100 \\
\text { hyd }\end{array}$ & $\begin{array}{l}\text { otovolt } \\
k W \text { fix } \\
\text { wer sys }\end{array}$ & $\begin{array}{l}\text { l, WES25 } \\
\text { acity gen } \\
\text { ad Solaxl }\end{array}$ & $\begin{array}{l}\text {-bladed, } \\
\text { Surr6CS2S } \\
\text { W solar in }\end{array}$ & $\begin{array}{l}\text { formance, relic } \\
\text { age battery typ }\end{array}$ & $\begin{array}{l}\text { size } 250 \mathrm{k} \\
\text { ic battery }\end{array}$ & $\begin{array}{l}\text { urbine, } \\
\text { Hydloos }\end{array}$ \\
\hline
\end{tabular}

Nineteen feasible configurations were identified among which the top ten configurations were found to be feasible. The $1^{\text {st }}$ most feasible components could generate $903 \mathrm{~kW}$ from the PV array, $5 \mathrm{~kW}$ from WES250 wind turbines, and 214kW from the micro-hydropower source. All these systems can produce energy from renewable sources. During off-peak hours, surplus energy can be stored in the batteries. Whereas during peak hours, high energy demands can be served by all power sources including battery storage.

\subsubsection{An economic evaluation of the hybrid system}

In the hybrid system, the package was run to obtain sensitive parameters. 243 sensitive parameters were identified. The least-cost was obtained at the design streamflow value of $1.296 \mathrm{~m}^{3} \cdot \mathrm{sec}^{-1}$, 
with the fuel cost incurring $0.65 \$ \ell^{-1}$, solar radiation of $6.13 \mathrm{kWh} \cdot \mathrm{m}^{-2} \cdot \mathrm{day}^{-1}$ and at the wind speed of 3.04 $\mathrm{m}^{\mathrm{s}} \mathrm{s}^{-1}$. However, the cost of wind and PV components is more delicate compared to micro hydropower. Besides, the diesel price also contributes to the cost variation for the system. Energy generation of the hybrid system increases when the number of renewable resources increases and vice versa.

The most feasible hybrid system power alternatives of the Seyemtribua village were analyzed considering the cost and benefits of the various system components available in the market. The cost of each component of the hybrid system is presented in terms of the NPC and the Levelized cost of energy (COE). The entire system configuration has almost constant lowest Levelized cost with COE of $0.052 \$$ $(\mathrm{kWh})^{-1}$ which is cheaper than that of EEPCO's outlay of $0.067 \$(\mathrm{kWh})^{-1}$. This means that the hybrid system can be affordable with different component configurations and without considering the sizes of the components. The most feasible hybrid system configuration of the system with the lowest NPC and operational cost is the system that incurs a net present value of about $\$ 6.72$ million which is fair and affordable (Table 4). This configuration can be achievable and may attract investment in the energy sector. The summary of the economic analysis of the hybrid system is presented in Table . 
Table 4. Economic analysis of the hybrid system

\begin{tabular}{lccccc}
\hline No & COE & $\begin{array}{c}\text { NPC } \\
(\$)\end{array}$ & $\begin{array}{c}\text { Operating cost } \\
(\$)\end{array}$ & $\begin{array}{c}\text { Initial capital cost } \\
(\$)\end{array}$ & $\begin{array}{c}\text { Renewable Fractions } \\
(\boldsymbol{\%})\end{array}$ \\
\hline 1 & 0.0515 & $6,720,726$ & 82,978 & $5,539,661$ & 94.4 \\
2 & 0.0515 & $6,728,730$ & 82,398 & $5,555,917$ & 94.4 \\
3 & 0.0515 & $6,732,261$ & 81,638 & $5,570,274$ & 94.5 \\
4 & 0.0515 & $6,733,564$ & 83,341 & $5,547,337$ & 94.4 \\
5 & 0.0515 & $6,741,158$ & 83,686 & $5,550,021$ & 94.3 \\
6 & 0.0515 & $6,741,370$ & 84,163 & $5,543,433$ & 94.4 \\
7 & 0.0515 & $6,747,639$ & 81,972 & $5,580,899$ & 94.4 \\
8 & 0.0515 & $6,748,329$ & 88,887 & $5,483,155$ & 94.9 \\
9 & 0.0515 & $6,750,069$ & 79,736 & $5,615,147$ & 94.6 \\
10 & 0.0515 & $6,753,436$ & 81,158 & $5,598,272$ & 94.5 \\
11 & 0.0516 & $6,755,895$ & 86,210 & $5,528,832$ & 94.1 \\
12 & 0.0516 & $6,757,059$ & 83,503 & $5,568,520$ & 94.4 \\
13 & 0.0516 & $6,758,524$ & 82,675 & $5,581,775$ & 94.4 \\
14 & 0.0518 & $6,760,404$ & 84,411 & $5,558,938$ & 94.3 \\
15 & 0.0517 & $6,760,573$ & 81,581 & $5,599,386$ & 94.5 \\
16 & 0.0518 & $6,761,183$ & 83,203 & $5,576,914$ & 94.4 \\
17 & 0.0517 & $6,765,723$ & 87,750 & $5,516,735$ & 94.1 \\
18 & 0.0517 & $6,767,655$ & 79,357 & $5,638,130$ & 94.8 \\
19 & 0.0517 & $6,770,695$ & 80,510 & $5,624,758$ & 94.8 \\
20 & 0.0517 & $6,774,275$ & $79,931.01$ & $5,636,579$ & 94.6 \\
\hline
\end{tabular}

The payback period determines the number of years required for the invested capital to be offset by resulting benefits. Hence, the payback period from the system is nearly 4 years and with a discount payback period of 4.12 years. The overall capital, operating, replacement, salvage, and mobilization cost of the most feasible hybrid system is presented in Table 5. 
Table 5. Results of NPC of the most feasible system obtained after the optimization process

\begin{tabular}{|c|c|c|c|c|c|c|}
\hline Components & $\begin{array}{l}\text { Capital } \\
\text { cost } \\
(\$)\end{array}$ & $\begin{array}{l}\text { Operating } \\
\text { cost } \\
(\$)\end{array}$ & $\begin{array}{l}\text { Replacement } \\
\text { cost } \\
(\$)\end{array}$ & $\begin{array}{l}\text { Salvage } \\
\text { value } \\
(\$)\end{array}$ & $\begin{array}{c}\text { Resource } \\
\text { mobilization cost } \\
(\$)\end{array}$ & $\begin{array}{c}\text { Total } \\
(\$)\end{array}$ \\
\hline $\begin{array}{l}\text { Generic 100kW Fixed } \\
\text { Capacity Genset }\end{array}$ & 8,000 & 57,446 & 12,285 & 1,540 & 313,144 & 389,336 \\
\hline Generic flat plate PV & $1,630,000$ & 128,521 & 0 & 0 & 0 & $1,750,000$ \\
\hline Generic Hydro 100kW & 120,000 & 170,802 & 0 & 0 & 0 & 290,802 \\
\hline HOMER load following & 1,000 & 285 & 0 & 0 & 0 & 1,285 \\
\hline SolaX X3-Hybrid10 & $2,750,000$ & 98,024 & 0 & 0 & 0 & $2,850,000$ \\
\hline Surrette 6 CS 25P & 705,600 & 125,539 & 337,021 & 81,229 & 0 & $1,090,000$ \\
\hline WES $30[250 \mathrm{kw}]$ & 325,000 & 712 & 48,960 & 28,906 & 0 & 345,766 \\
\hline Overall System & $5,540,000$ & 581,329 & 398,266 & 111,674 & 313,144 & $6,720,000$ \\
\hline
\end{tabular}

\section{Conclusions}

Assessment of the feasibility of a hybrid power system composed of micro-hydro, solar, and wind energy was studied for the Geba catchment, Northern Ethiopia. A particular village named Seyemetribua was considered for power demand assessment as there exists a large potential for renewable energy sources in the village. Several datasets were collected and used as input for hydrologic and energy models. The HOMER software package was used to evaluate the potential power generated from the alternative energy sources. Economic analysis of both the stand-alone and hybrid systems was conducted. The following conclusions were made from this study.

It can be concluded that more than $50 \%$ of the power output for the hybrid system for Seyemtribua village can be harnessed from a hydropower system with a Levelized cost of energy less than that of the EEPCO $(0.067 \$ / \mathrm{kWh})$. A standalone system (e.g., hydropower) cannot satisfy the demand of the community. However, a power supply that combines any one of the systems with microhydropower can satisfy the energy demand of the community except for peak power load hours. The deficiency in power from the combination of wind and solar cannot satisfy the load of the community in most cases. The most promising combination is when the micro-hydro, wind, and solar output operate together which significantly narrows the power supply-demand gap. The power supply from the hybrid 
system is sufficient on a monthly or annual basis. However, close observations show that it fails to satisfy the demand in peak load hours daily. This power deficit during peak hours might be curbed by the introduction of a supplementary generator or alteration of power consumption behavior. We recommend the latter approach since there is surplus power production during the off-peak hours.

The economic analysis of the hybrid system with the lowest Levelized COE and the net present cost is the one with a COE of approximately 0.052 and incurring nearly $\$ 6.72$ million NPC. The corresponding simple payback period of 3.65 or 4.12 years on discount is suggested. This configuration is an economically feasible system and can easily charm stakeholders, practitioners, and donors to pay for and benefit from it in a short period.

\section{Availability of data and materials}

The datasets used in the current study are available from the corresponding author on reasonable request.

\section{Competing Interests}

The authors declare that there are no competing interests regarding the publication of this work.

\section{Funding}

This research work work was carried out with the partial financial support of the Ethiopian Roads Authority (ERA) through a capacity-building program to carry out the research. The authors would like to acknowledge the assiatnce provided by the Ethiopian Roads Authority(ERA) with this regard.The authors also acknowledge the assistance made by Wag Himra Zone Water Supply Construction \& Supervision Core Processing Unit, Bureau of Water, 
Irrigation and Energy, Ethiopia for providing leave of absence to the $1^{\text {st }}$ author to collect field data during the research period.

\section{Authors Contributions}

Gezahegn, G.T. has collected the primary and secondary data and analyzed power potential data of the area. He also has written the first draft report of the study. Hatiye, S.D. has supervised the data collection, analysis, and interpreted the results. Ayana, M.T. has checked the feasibility of the hybrid systems for the particular interest area and contributed to writing the manuscript. Ayalew, A.T. has assisted in arranging the data and provided the shapefiles of the study area. Minda, T.T.has greatly contributed by plotting the figures in python and edited the manuscript. All authors read and approved the final manuscript.

\section{Acknowledgments}

The Ministry of Water, Irrigation, and Electricity, and the National Metrological Service Agency are acknowledged for providing the necessary data. The community at the Seyemtribua area is appreciated for their support during the field survey and data collection. Special thanks are indebted to Mr. Tamirat Tayassa for providing his HTC AVM-06 Digital Anemometer for the measurement of wind data. Arba Minch University and the zonal water bureau, WagHimra are greatly acknowledged.

\section{References}

1. Taylor PG, Abdalla K, Quadrelli R, \& Vera I (2017) Better energy indicators for sustainable development. Nature Energy, 2(8), 1-4. https://doi.org/10.1038/nenergy.2017.117

2. Barber BB (2020) Access to Energy. Japan's Relations with Muslim Asia, 53-80. https://doi.org/10.1007/978-3-030-34280-7_3 
3. Degefu DM, He W, \& Zhao JH (2015) Hydropower for sustainable water and energy development in Ethiopia. Sustainable Water Resources Management, 1(4), 305-314. https://doi.org/10.1007/s40899-015-0029-0

4. Aydin NY, Kentel E, \& Sebnem Duzgun H (2013) GIS-based site selection methodology for hybrid renewable energy systems: A case study from western Turkey. Energy Conversion and Management, 70, 90-106. https://doi.org/https://doi.org/10.1016/j.enconman.2013.02.004

5. Hassan Q, Jaszczur M, \& Abdulateef J (2016) Optimization of $\{$ PV $\} /\{$ WIND $\} /\{$ DIESEL $\}$ Hybrid Power System in $\{$ HOMER $\}$ for Rural Electrification. Journal of Physics: Conference Series, 745, 32006. https://doi.org/10.1088/1742-6596/745/3/032006.

6. Ritchie H, \& Roser M (2019) Renewable Energy "Access to Energy" Published online at OurWorldInData.org. Retrieved from: 'https://ourworldindata.org/energy-access' .Accessed 20 Jan 2021.

7. Woodroofe R (1996) Omo Gibe River basin integrated development Master plan study Final report Vol. III and VI.

8. IPPC (2014) Climate Change 2014: Impacts, Adaptation, and Vulnerability. Part B: Regional Aspects. Contribution of Working Group II to the Fifth Assessment Report of the Intergovernmental Panel on Climate Change [Barros, V.R., C.B. Field, D.J. Dokken, M.D. Mastrandre].

9. Asrari A, Ghasemi A, \& Javidi MH (2012) An economic evaluation of hybrid renewable energy systems for rural electrification in Iran-A case study. Renewable and Sustainable Energy Reviews, 16(5), 3123-3130. https://doi.org/https://doi.org/10.1016/j.rser.2012.02.052.

10. Kirubakaran A, Jain S, \& Nema RK (2009) A review on fuel cell technologies and power electronic interface. Renewable and Sustainable Energy Reviews, 13(9), 2430-2440. https://doi.org/https://doi.org/10.1016/j.rser.2009.04.004.

11. Hoseinzadeh S, Ghasemi MH, \& Heyns S(2020) Application of hybrid systems in the solution of low power generation at hot seasons for micro-hydro systems. Renewable Energy, 160, 323-332. 
https://doi.org/https://doi.org/10.1016/j.renene.2020.06.149.

12. Ye B, Zhou M, Yan D, \& Li Y (2020) Multi-Objective Decision-Making for Hybrid Renewable Energy Systems for Cities: A Case Study of Xiongan New District in China. Energies, 13(23). https://doi.org/10.3390/en13236223.

13. Penche (2004) Guide on How to Develop a Small Hydropower Plant. In European Small Hydropower Association. http://citeseerx.ist.psu.edu/viewdoc/download?doi=10.1.1.172.1731\&rep=rep1\&type=pdf. Accessed 25 Jan 2021.

14. Asfar J, Atieh A, Al-Mbaideen R (2019) Techno-economic analysis of a microgrid hybrid renewable energy system. Journal Européen Des Systèmes Automatisés, 52(4), 415-423.

15. Pedia E (2013) Annual Report. Energy pedia UG (haftungsbeschränkt).

16. Teske S, Nagrath K, Morris TDK (2019) Renewable Energy Resource Assessment. In Achieving the Paris Climate Agreement Goals (pp. 161-173). Springer.

17. Martins FR, Pereira EB, \& Abreu SL (2007) Satellite-derived solar resource maps for Brazil under SWERA project. Solar Energy, 81(4), 517-528. https://doi.org/https://doi.org/10.1016/j.solener.2006.07.009.

18. Mazengia DH (2010) Ethiopian Energy Systems : Potentials, Opportunities and Sustainable Utilization (Dissertation). Uppsala University.

19. Teffera B, Assefa B, Björklund A, \& Assefa G (2021) Life cycle assessment of wind farms in Ethiopia. International Journal of Life Cycle Assessment, 26(1), 76-96. https://doi.org/10.1007/s11367-020-01834-5.

20. Gaddada S, and Kodicherla SPK (2016) Wind energy potential and cost estimation of wind energy conversion systems (WECSs) for electricity generation in the eight selected locations of Tigray region (Ethiopia). Renewables: Wind, Water, and Solar, 3(1). https://doi.org/10.1186/s40807-016-0030-8.

21. Hailu AD, and Kumsa DK (2020) Ethiopia renewable energy potentials and current state. AIMS 
Energy, 9(1), 1-14. https://doi.org/10.3934/ENERGY.2021001.

22. Kebede KY \& Mitsufuji T (2017) Technological innovation system building for the diffusion of renewable energy technology: A case of solar PV systems in Ethiopia. Technological Forecasting and Social Change, 114, 242-253. https://doi.org/https://doi.org/10.1016/j.techfore.2016.08.018

23. Khan B \& Singh P (2017) Optimal Power Flow Techniques under Characterization of Conventional and Renewable Energy Sources: A Comprehensive Analysis. Journal of Engineering, 2017, 9539506. https://doi.org/10.1155/2017/9539506

24. Mohammed YS, Mustafa MW \& Bashir N (2014) Hybrid renewable energy systems for off-grid electric power: Review of substantial issues. Renewable and Sustainable Energy Reviews, 35, 527-539. https://doi.org/https://doi.org/10.1016/j.rser.2014.04.022.

25. Gezahegn GT (2019) Potential Assessment of Small Hydro, Wind, Solar Hybrid Power of Geba Catchment for Off Grid Rural Electrification, Ethiopia. Msc. Thesis, Arba Minch University, Ethiopia (unpublished).

26. Girma Z (2016) Techno-Economic Feasibility of Small Scale Hydropower in Ethiopia: The Case of the Kulfo River, in Southern Ethiopia. Journal of Renewable Energy, 2016, 8037892. https://doi.org/10.1155/2016/8037892.

27. Wagesho N, Goel NK \& Jain MK (2013) Temporal and spatial variability of annual and seasonal rainfall over Ethiopia. Hydrological Sciences Journal, 58(2), 354-373. https://doi.org/10.1080/02626667.2012.754543.

28. Wubet T, Kottke I, Teketay D \& Oberwinkler, F (2003) Mycorrhizal status of indigenous trees in dry Afromontane forests of Ethiopia. Forest Ecology and Management, 179(1), 387-399. https://doi.org/https://doi.org/10.1016/S0378-1127(02)00546-7.

29. Raghunadh YMK, Chakrapani M, Bededa RD, Vijay PBG (2020) Assessment of Unconventional and Conventional Off-Grid Power Source for Rural Areas in Ethiopia. In: Narasimham G., Babu A., Reddy S., Dhanasekaran R. (eds) Recent Trends in Mechanical Engineering. Lecture Notes in Mechanical Engineering. Springer, Singap. Recent Trends in Mechanical Engineering, 737-744. 
https://doi.org/10.1007/978-981-15-1124-0_65

30. Raveena B, Rao B, \& Gouthamkumar N (2018) Optimization of Hybrid off Grid Power System Using HOMER software. 2018 3rd IEEE International Conference on Recent Trends in Electronics, Information Communication Technology (RTEICT), 696-700. https://doi.org/10.1109/RTEICT42901.2018.9012219

31. Sparks AH (2018) NASA power : A NASA POWER Global Meteorology, Surface Solar Energy and Climatology Data Client for R Summary and Statement of Need. 3, 3-5. https://doi.org/10.21105/joss.01035.

32. Moiz A, Kawasaki A, Koike T.and Shrestha M (2018) A systematic decision support tool for robust hydropower site selection in poorly gauged basins. Applied Energy. https://doi.org/10.1016/j.apenergy.2018.04.070.

33. Paulo RJ, M., S. L. G., Ana H, \& APR (2018) Site Selection for Hydropower Development: A GIS-Based Framework to Improve Planning in Brazil. Journal of Environmental Engineering, 144(7), 4018051. https://doi.org/10.1061/(ASCE)EE.1943-7870.0001381.

34. De Silva RP, Dayawansa NDK, \& Ratnasiri MD (2007) A comparison of methods used in estimating missing rainfall data. Journal of Agricultural Sciences, 3(2), 101. https://doi.org/10.4038/jas.v3i2.8107.

35. Searcy JK, \& Hardison CH (1960) Double-mass curves (Issue 1541). US Government Printing Office.

36. Buishand TA (1982) Some methods for testing the homogeneity of rainfall records. Journal of Hydrology, 58(1), 11-27. https://doi.org/https://doi.org/10.1016/0022-1694(82)90066-X.

37. Feldman AD (2000) Hydrologic modeling system HEC-HMS: technical reference manual. US Army Corps of Engineers, Hydrologic Engineering Center.

38. HOMER Energy LLC (2019) HOMER Pro user manual. https://www.homerenergy.com/products/pro/docs/3.13/index.html.

39. Givler T, \& Lilienthal P (2005) Using HOMER Software, NREL's Micropower Optimization 
Model, to Explore the Role of Gen-sets in Small Solar Power Systems; Case Study: Sri Lanka.

40. Lambert T, Gilman P, \& Lilienthal P (2006) Micropower system modeling with HOMER. In Integration of alternative sources of energy (pp. 1(1), 379--385). John Wiley \& Sons, ISBN 0471712329.

41. Killingtveit $\AA$ (2014). Chapter 21 - Hydroelectric Power. In T. M. Letcher (Ed.), Future Energy (Second Edition) (Second Edi, pp. 453-470). Elsevier. https://doi.org/https://doi.org/10.1016/B978-0-08-099424-6.00021-1

42. Fuladipanah M \& Sangi E (2015) Possibilities of Applying Hydrological Methods for Determining Environmental Flows in Select Catchments of the Upper Dunajec Basin. Pol. Journal of Environmental Studies, 24(6), 2663-2676.

43. Tong W (2011)Wind power generation and wind turbine design. In Choice Reviews Online (Vol. 48, Issue 07). WIT press. https://doi.org/10.5860/choice.48-3904

44. Bekele G, \& Tadesse G (2012) Feasibility study of small Hydro/PV/Wind hybrid system for offgrid rural electrification in Ethiopia. Applied Energy, 97, 5-

15. doi:10.1016/j.apenergy.2011.11.059.

45. Wu J, Zhang B, Li H, Li Z, Chen and Miao X (2014) Statistical distribution for wind power forecast error and its application to determine optimal size of energy storage system. Electrical Power and Energy Systems, 55 100-107. https://doi.org/10.1016/j.ijepes.2013.09.003.

46. Stull R (2000). Meteorology for scientists and engineers. Brooks/Cole.

47. Nakomčić-Smaragdakis Branka B and Dragutinović Nataša G (2016) Hybrid renewable energy system application for electricity and heat supply of a residential building. Thermal Science, 20(2), 695-706. https://doi.org/10.2298/TSCI150505144N

48. Yahyaoui I, Atieh A, Tadeo F, \& Tina GM (2017) Energetic and economic sensitivity analysis for photovoltaic water pumping systems. Solar Energy, 144, 376-391. https://doi.org/https://doi.org/10.1016/j.solener.2017.01.040.

49. Ayodele TR, \& Ogunjuyigbe ASO (2015) Prediction of monthly average global solar radiation 
based on the statistical distribution of clearness index. Energy, 90, 1733-1742.

https://doi.org/https://doi.org/10.1016/j.energy.2015.06.137

50. Mousavi Maleki SA, Hizam H, \& Gomes C (2017) Estimation of hourly, daily and monthly global solar radiation on inclined surfaces. MDPI, 10(1). https://doi.org/10.3390/en10010134

51. Farret FA, \& Simoes MG (2006) Integration of alternative sources of energy. John Wiley \& Sons.

52. Singh AS, \& Masuku MB (2014) Normality And Data Transformation for Applied Statistical Analysis. International Journal of Economics, Commerce and Management, 2(7), 1-11.

53. Degefu W (1987) Some aspects of meteorological drought in Ethiopia. Cambridge University Press.

54. Fikru MG, Gelles G, Ichim, AM, \& Smith JD (2019) Notes on the Economics of Residential Hybrid Energy System. Energies, 12(14). https://doi.org/10.3390/en12142639

55. Hara R (2016) Chapter 5 - Prediction of wind power generation output and network operation. In T. Funabashi (Ed.), Integration of Distributed Energy Resources in Power Systems (pp. 109131). Academic Press. https://doi.org/https://doi.org/10.1016/B978-0-12-803212-1.00005-2

56. Balakrishnan PS, Shabbir MF, Siddiqi A \& Wang X (2020) Current status and future prospects of renewable energy: A case study. Energy Sources, Part A: Recovery, Utilization, and Environmental Effects, 42(21), 2698-2703. https://doi.org/10.1080/15567036.2019.1618983

57. Paska J, Biczel P, \& Kłos M (2009) Hybrid power systems - An effective way of utilizing primary energy sources. Renewable Energy, 34(11), 2414-2421. https://doi.org/https://doi.org/10.1016/j.renene.2009.02.018

58. Goudarzi N, Mohammadi K, St. Pé A, Delgado R., \& Zhu W (2020) Wind Resource Assessment and Economic Viability of Conventional and Unconventional Small Wind Turbines: A Case Study of Maryland. Energies, 13(22). https://doi.org/10.3390/en13225874

59. Energy W (2019) Global Wind Report.

60. Solar Choice (2019) Residential Solar PV Price Index. 
